\title{
AVAR KORI FÖLDBE MÉLYÍTETT ÉS FÖLDFELSZÍNI ÉPÜLETEK RÁKÓCZIFALVA-BAGI-FÖLDEK LELÖHELYEN
}

\author{
KONDÉ ZSÓFIA*
}

\begin{abstract}
The study offers a typology, a comparison and possible reconstructions of the 45 sunken and 15 above-ground buildings, the latter outlined by post-holes, uncovered at the Avar period settlement site of Rákóczifalva-Bagi-földek. The period's few analogous sunken and above-ground houses are reviewed in detail. The structures uncovered at the site reflect a rich diversity of architectural forms, calling for a re-assessment of our earlier view of Avar period settlements.
\end{abstract}

Keywords: Avar period, settlement research, reconstruction of buildings, log houses, aboveground buildings

A tanulmány a Rákóczifalva-Bagi-földek lelöhelyen feltárt avar kori telep 45 veremházának és 15, cölöphelyek által kirajzolt felszini épitményének tipológiai és összehasonlító elemzésével és rekonstrukciós lehetőségeivel foglalkozik. Kiemelten tárgyalja a kevés avar kori párhuzammal rendelkezö, földbe mélyített és földfelszíni épületeket. A bemutatott objektumok alapján nagyon változatos építészeti kép vázolható fel, módositva az avar kori településekről kialakult véleményeket.

Kulcsszavak: avar kor, telepkutatás, épületrekonstrukció, boronaház, földfelszini épületek

\section{A lelóhely}

A Jász-Nagykun-Szolnok megyei Rákóczifalva közelében 2006-2007-ben folytatott, a Vásárhelyiterv miatt szükségessé vált megelőző feltárások számos lelőhelyet érintettek. Így a RákóczifalvaBagi-földek 2., 5., 8A, 8. és 12. lelőhelyeket, amelyek területét északi, déli és nyugati irányból a Tisza és hordalékos területe határolja, kelet felől pedig a folyó menti magasparthoz kapcsolódik, félszigetszerúen nyúlik be a tiszai ártérbe. ${ }^{1}$

A kézirat érkezett: 2015. május 12.

* Kondé Zsófia. ELTE BTK Régészettudományi Intézet, 1088 Budapest, Múzeum krt. 4/B; konde.zsofia@gmail.com

1 A lelőhelyek feltárásáért és a leletanyag feldolgozásának lehetőségéért az ELTE BTK Régészettudományi Intézete munkatársainak tartozom köszönettel: KovÁcs-SEBÖK-
A különböző időszakokban - a neolitikumtól a szarmata és gepida koron át ${ }^{2}$ egészen a késő avar időszakig - a megtelepedés ezen a magasparton, a magasabb dombhátakhoz rendeződve történt (1. kép). Az öt különböző számmal jelölt lelőhely közel 14 hektárt foglal el, amelyból körülbelül másfél hektárnyi, nem egybefüggő területet 8-9. századi avar kori települési objektumok csoportjai fednek. ${ }^{3}$

SZABÓ-VÁCZI 2007; SZABÓ-SEBŐK 2007a; SZABÓ-SEBÖK 2007b; VÁcZI-Kovács 2007a; VÁcZI-KovÁcs 2007b; KovÁcs-SEBőKSZABÓ-VÁCZI 2008.

2 A kora népvándorlás kori telepjelenségek feldolgozását készülő doktori disszertációja részeként Masek Zsófia végzi: MASEK 2009; MASEK 2012.

3 Ezen objektumok és leletanyaguk feldolgozása képezte 2009es alapszakos záródolgozatom és 2012-es szakdolgozatom témáját. A kerámia leletanyag 4,5\%-a lassúkorongolt technikával, 95,5\%-a korong használata nélkül készült. Formai 


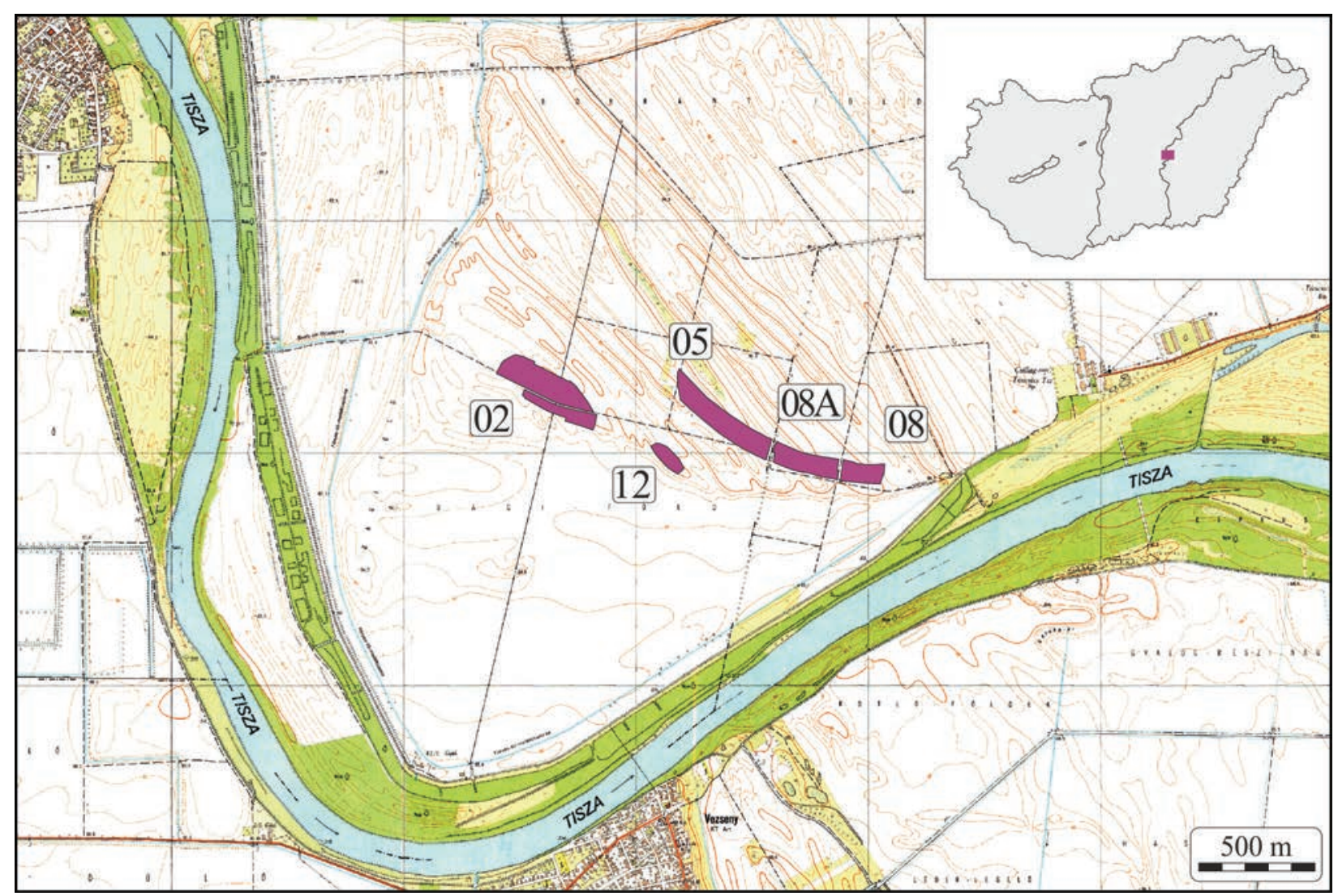

1. kép. Rákóczifalva-Bagi-földek földrajzi elhelyezkedése és a feltárt területek

Fig. 1. Rákóczifalva-Bagi-földek, location of the site and the excavated area

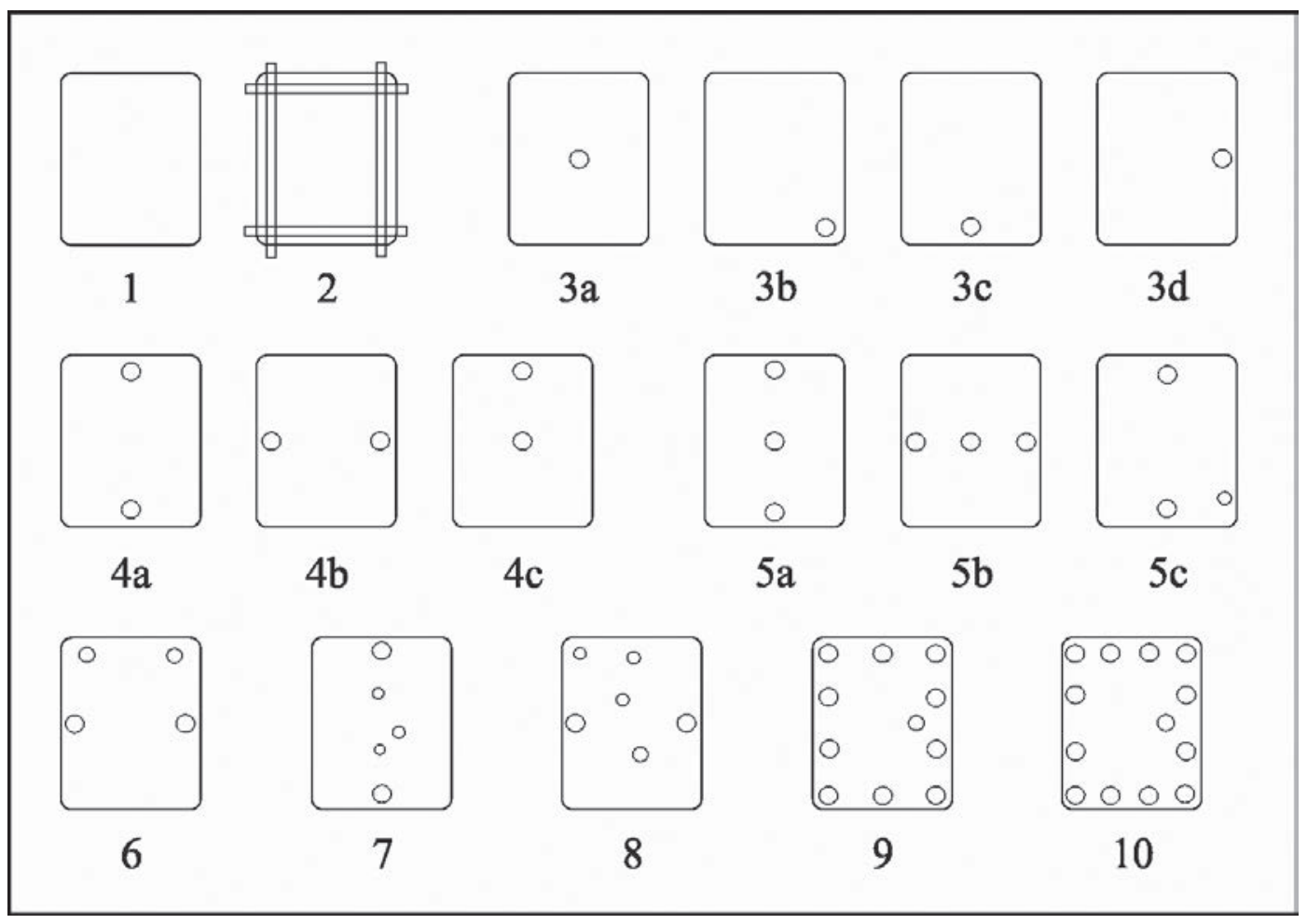

2. kép. Rákóczifalva-Bagi-földek, a lelőhelyen feltárt veremházak szerkezeti variációi

Fig. 2. Rákóczifalva-Bagi-földek, structural variants of the sunken houses uncovered at the site 
A feltárt területek közül legnyugatabbra elterülő Rákóczifalva-Bagi-földek 2. lelőhely nagy részén késő neolitikumba tartozó objektumok kerültek elő; ezek között három csoportban sû́rüsödtek avar kori objektumok. 41 objektumot leletanyag alapján, 14 további jelenséget pedig ezekkel azonos vagy ezekhez igazodó tájolásuk alapján lehetett ehhez a korhoz kötni. A gödrök, árkok és a 16 veremház mellett számos, oszlophelyek alkotta jelenség rajzolódott ki, amelyek kerítések, terelőfalak, karámok vagy akár földfelszíni lakóépületek is lehettek (3. kép A-C).

A 2. lelőhelytől délkeletre helyezkedett el a 12. lelőhely, amelynek közepén egy néhány gödörből, egy árokból és két földbe mélyített épületből álló, tanyaszerú települési egység képviselte az avar kort (3. kép D).

Az 5., 8A és 8. számmal jelölt lelőhelyek területileg egy egységet alkottak. Az 5. lelőhelyen a neolitikus, szarmata és gepida objektumok mellett, a legkeletibb részen ÉK-DNy-i irányban sorakoztak az avar kori objektumok: egy gödör, hat veremház és egy ezekkel azonos tájolású, oszlophelyek által kirajzolt épület nyoma (4. kép A). A 8A lelőhely középső részét egy 250 síros avar temető, ${ }^{4}$ valamint két csoportba rendeződve öszszesen 15, szintén avar kori települési objektum foglalta el, a neolitikus, rézkori, késő bronzkori, szarmata és gepida objektumok mellett. A temetőtől DNy-i irányban hét, félkör alakban elhelyezkedő, földbe mélyített épület került elő (4. kép B). A temetótől ÉK-re pedig további hét, földbe mélyített épület, egymástól közel azonos távolságban, U alakba rendezve (4. kép C). A 8. lelőhelyen 13 avar kori települési objektum került feltárásra két csoportban, a terület ÉNy-i és ÉK-i részén (4. kép $D-E$ ). Az ÉNy-i csoportban négy, egymástól 5-10 méterre álló veremház alkotott egy ÉK-DNy-i sort, és egy további épület állt ezektől nagyjából 30 méterre ÉNy-ra. Az ÉK-i csoportban további két épület volt, egymástól 30 méterre. E két objektumcsoport között terült el egy 58 sírból álló, teljes egészében feltárt késő avar kori temető. ${ }^{5}$

szempontból a lassúkorongolt edények fazekakként rekonstruálhatók, a korongolatlan edények között pedig csészék/ bögrék, változatos kialakítású fazekak, tálak, bográcsok és sütőharangok találhatók. Ez utóbbi csoport több képviselőjét különböző pecsételt minták díszítették. A leletanyag részletesebb tipologizálásával, az értelmezésére vonatkozó eredményekkel és az ezek alapján levonható következtetésekkel foglalkozó tanulmány: KONDÉ s. a.

4 MÁCSAI 2011.

SCHMID 2009.

\section{Földbe mélyített padlójú épületek ${ }^{6}$}

A bemutatott településrészleteken összesen 45 földbe mélyített padlójú épület maradványát tárták fel. Ezekre egységesen jellemző a lekerekített sarkú téglalap, téglalap vagy négyzet alaprajz, egyenes fal és a tapasztás nélküli padló. Átlagos méretük 9,5 $\mathrm{m}^{2}$; a legkisebb alapterülete $7 \mathrm{~m}^{2}$, a legnagyobbé $18,45 \mathrm{~m}^{2}$ volt. Relatív mélységük igen eltérő, 10-100 cm közötti, ez azonban az eltávolított humuszréteg különböző vastagságának eredménye is lehet. Bejáratra utaló, lépcsőszerú lemélyítést az épületek falánál öt esetben figyeltek meg a feltárók.

"Szabályos", boltíves, átégett sütőfelülettel rendelkezó kemence csupán hat épületben került elő, a sarokba vájva vagy az épületen túlnyúlva (5. kép 3, 4). Tizenhárom esetben az épületek oldalában félköríves, kemencéhez hasonló bevájás volt, ezekben azonban átégés nyomát csupán egyetlen esetben lehetett megfigyelni. Rendeltetésük így nehezen értelmezhetó; nem egyértelmú, hogy a fózéshez/fútéshez kapcsolódtak (5. kép 2). ${ }^{7}$ Ezzel a jelenséggel párhuzamosan ugyanakkor sok esetben megfigyelhető, hogy az épületek közepén a padló néhány foltban átégett. A foltok alighanem tüzelóhelyek maradványai voltak. ${ }^{8}$ A kemence nélküli, parázson történő ételkészítés gyakori voltát támogatja a lelőhelyen talált nagy mennyiségú sütőharang-töredék,

6 Noha a Grubenhaus tükörfordítása, a gödörház vagy veremház szavak esetében asszociálhatunk kizárólag lakó funkciójú épületre, a kutatásban mára többnyire elfogadott ez a két kifejezés - és nem csupán olyan épületek esetében, amelyeket bizonyíthatóan lakóépületként használtak. Tudatosan kerültem azonban a "félig" földbe mélyített épület terminológiát, amely - helytelenül - magában foglal egy többnyire bizonyíthatatlan adatot, az egykori épület mélységét. Az elnevezésekról bővebben: TAKÁCS 2001, 7; MESTERHÁZY 2002, 85; ŠALKOVSKÝ 2009, 273-274.

7 Ez a jelenség párhuzamba állítható a 2. eperjesi ház falában megfigyelt bemélyedéssel, ahol átégést szintén nem lehetett megfigyelni: BÁLINT 1991, 17, Taf. VII.1. További párhuzamként említhetők a balatonőszödi avar kori település épületeiben talált, oldalfalba vájt, tapasztás nélküli túhelyek, amelyekben azonban a feltáróknak sikerült enyhe átégés nyomait és köveket megfigyelniük. Véleményük szerint ezek az objektumok a felforrósított kövek tárolására alkalmas parázstartó túzhelyek maradványai lehettek: BELÉNYESY-MERSDORF 2004, 44, 56, 8. kép. A publikálók hasonló véleményt fogalmaztak meg az egyik, Szeged-Fertő lelőhelyen feltárt épület falba vájt gödre kapcsán is, amelynek alján sütőharang-töredékek is előkerültek: BENEDEK-PÓPITY 2010, 198.

8 Kovalovszki Júlia a dobozi telep legtöbb épületében kisméretú, tapasztás nélküli, gyengén kiégett kemencét tárt fel, amelyet minden esetben kiegészített egy az épület közepén talált túzhelymaradvány. Használatának módjára utal az egyik épületben ezen a nyílt tüzelőhelyen előkerült nagy mennyiségú sütőharang-töredék: KovALOVSZKI 1975, 209. 


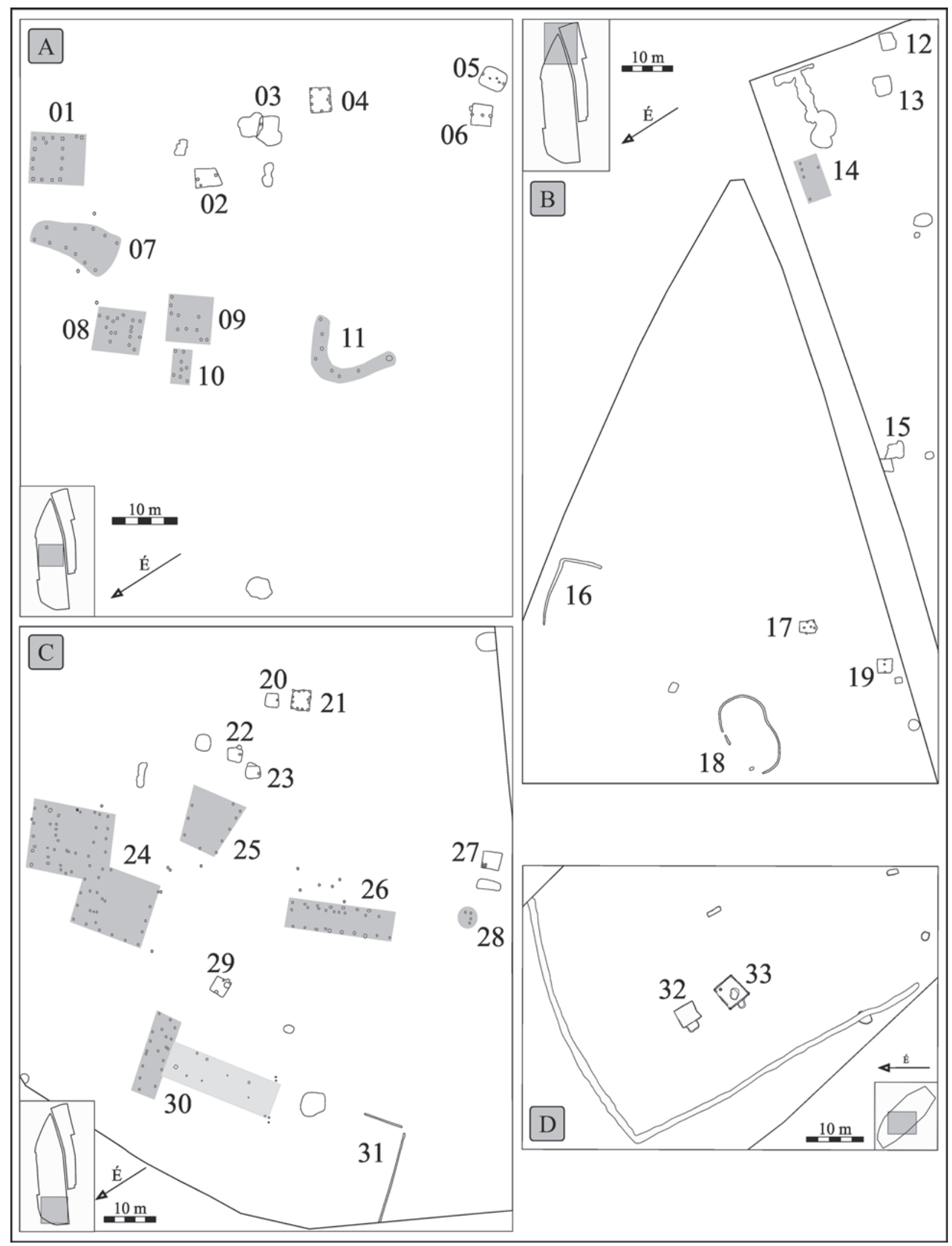

3. kép. Rákóczifalva-Bagi-földek 2. lelőhely középső (A), délkeleti (B) és északnyugati (C) részén feltárt avar kori objektumok, valamint Rákóczifalva-Bagi-földek 12. lelőhely (D) avar kori településrészlete

Fig. 3. Rákóczifalva-Bagi-földek 2, Avar period features uncovered in the site's middle part (A), south-eastern fringes (B) and in the site's north-western part (C); Rákóczifalva-Bagi-földek 12, Avar period features of the site (D) 
amely edénytípus használata független a kemencéktől. ${ }^{9}$

Az épületen belül talált oszlophelyek, illetve egyéb, fal- és tetőszerkezetre utaló jelenségek tíz változatban jelentek meg a lelőhelyen (1-10. típus: 2. kép), az ezek alapján rekonstruálható épületek azonban négy szerkezeti csoportba oszthatók (8. kép).

\section{1. típus: oszlophely nélküli épületek (2. kép 1)}

A veremházak 31\%-ában, 14 objektumban nem volt oszlophely, és ezek egyenlő arányban fordultak elő az összes lelőhelyen. Közülük 13 téglalap, egy négyzet alakú; nagyságuk 7 és $12,56 \mathrm{~m}^{2}$ között, relatív mélységük 20 és $100 \mathrm{~cm}$ között mozgott. Bejáratra utaló, lépcsőzetes lemélyülést három esetben figyeltek meg: két épületnél a DNy-i oldalnál, a harmadiknál az ÉK-i oldal közepén (3. kép 13, 32; 4. kép 61). Kemence három épületben maradt meg: az ÉNy-i sarokban egy padkára épített, enyhén kiégett sütőfelületú kemence (3. kép 27), a DK-i sarokban egy kerek, földbe vájt, átégett kemence (4. kép 59; 5. kép 4), valamint egy a D-i oldal Ny-i falából kinyúló kemence boltozatindítással, sütőfelületének alapozásában állatcsont- és kerámiatöredékekkel (4. kép 41; 5. kép 1). Három épület DNy-i falában (4. kép 49-51) és egy negyedik épület DK-i falában (7. kép 36) mutatkozott „,bevájás”, amelyek közül csupán az egyik felszínén figyeltek meg égésnyomokat (4. kép 49).

\section{2. típus: oszlophely nélküli épület gerendalenyomattal (2. kép 2)}

A 12. lelóhely egyik téglalap alakú, egyenes oldalú, egyenes aljú épületének falai mentén, azon belül egy 19-22 cm széles, 10-15 cm mély árok nyoma bontakozott ki a feltárás során (3. kép 33; 6. kép 1-3). A három oldal mentén megszakítás nélkül, a negyedik oldal mentén két rövidebb megszakítással körbefutó árkok végei a sarkoknál metszették egymást, majd a falban folytatódtak. Az épület DNy-i falánál, annak közepén egy 130 cm széles, sekély, 10-15 cm-es lemélyítés, az épület É-i sarkánál egy $45 \mathrm{~cm}$ átmérőjú, vörös, átégett folt rajzolódott ki. 18,45 $\mathrm{m}^{2}$-rel ez volt a legnagyobb alapterületú épület; a sárga altalajtól számított mélysége 30-40 cm.

\section{3.a-d típus: épületek egy oszlophellyel (2. kép 3.a-d)}

A 2., 5. és 8. lelőhelyen, összesen hat épületben (13\%) került elő csupán egy oszlophely; három

\footnotetext{
9 VIDA 2011, 711-713.
}

esetben a DNy-i oldal, egy esetben az ÉK-i oldal, egy esetben az épület közepén, valamint egy további esetben a DK-i sarokban. Közülük öt téglalap és lekerekített téglalap, egy pedig négyzet alakú. Faluk egyenes, gödörméretük 7,56-10,2 $\mathrm{m}^{2}$, relatív mélységük $32-70 \mathrm{~cm}$ közötti. Bejárat nyomát nem lehetett megfigyelni, bár az egyik épület É-i fala mentén talált "padka" összefüggésben lehet a bejárattal (4. kép 34), ahogyan egy másik épület K-i oldalának kiszélesedése és lemélyülése is (3. kép 23). Egy épületnek döngölt padlója volt (4. kép 34). Egy épület ÉK-i és két épület DK-i sarkában találtak ovális, átégés nélküli bemélyítést (3. kép 20, 22; 4. kép 34); ezek közül az egyik épület padlójának közepén két átégett folt is kirajzolódott (4. kép 34).

\section{4a-c típus: épületek két oszlophellyel (2. kép 4a-c)}

Mindegyik lelőhelyen került eló olyan épületmaradvány, amelyben két oszlophely maradt a tartószerkezetből. A tizenegy épületből kettőnél $(24,4 \%)$ az oszlophelyek a hossztengely mentén, tehát a rövidebb oldalak közepén (3. kép 29; 4. kép $53)$, hatnál a rövidebb oldalak tengelyén, tehát a hosszabb oldalak közepén helyezkedtek el (4. kép $38,42,44,45,52,60)$. Két négyzet alakú épületben az oszlophelyek egy-egy párhuzamos oldal közepén kerültek elő (4. kép 54, 58). Az egyik épületben az egyik oszlop az egyik rövid oldal közepén, a másik az épület közepén állt (4. kép 37). Méretük 7,13-13,32 $\mathrm{m}^{2}$ közötti, relatív mélységük 16-70 cm-ig terjedt. Ennél a típusnál két esetben figyeltek meg az épület gödrén túlnyúló, ahhoz a szájnyílással csatlakozó kemencemaradványt sütőfelülettel és boltozatindítással (4. kép 45, 60). Egy harmadik esetben a kemencét a DK-i sarokba vájták (4. kép 58). Égésnyom nélküli, félköríves bemélyítés három épületben került elő a DNy-i, egy épületben a DK-i sarok közelében (4. kép 37, 38, 42, 54). Két objektum közepén figyeltek meg átégett foltokat (4. kép 42, 52).

\section{5a-c típus: épületek három oszlophellyel (2. kép $5 a-c)$}

A 2., 8A és 8. lelőhelyen, összesen hét épületben $(15,5 \%)$ került elő három oszlophely. Az ebbe helyezett ágasfák tengelye három esetben a hoszszanti tengelyhez igazodott, tehát két oszlophely volt a két rövidebb oldal közepén és egy az épület közepén (3. kép 06; 4. kép 43, 48; 5. kép 2), három esetben pedig a rövidebb oldalhoz igazították (3. kép 19; 4. kép 46, 56). A hetedik három oszlophelyes objektumban két oszlophely került elő a két rövidebb oldal közepén, az egyik rövid 


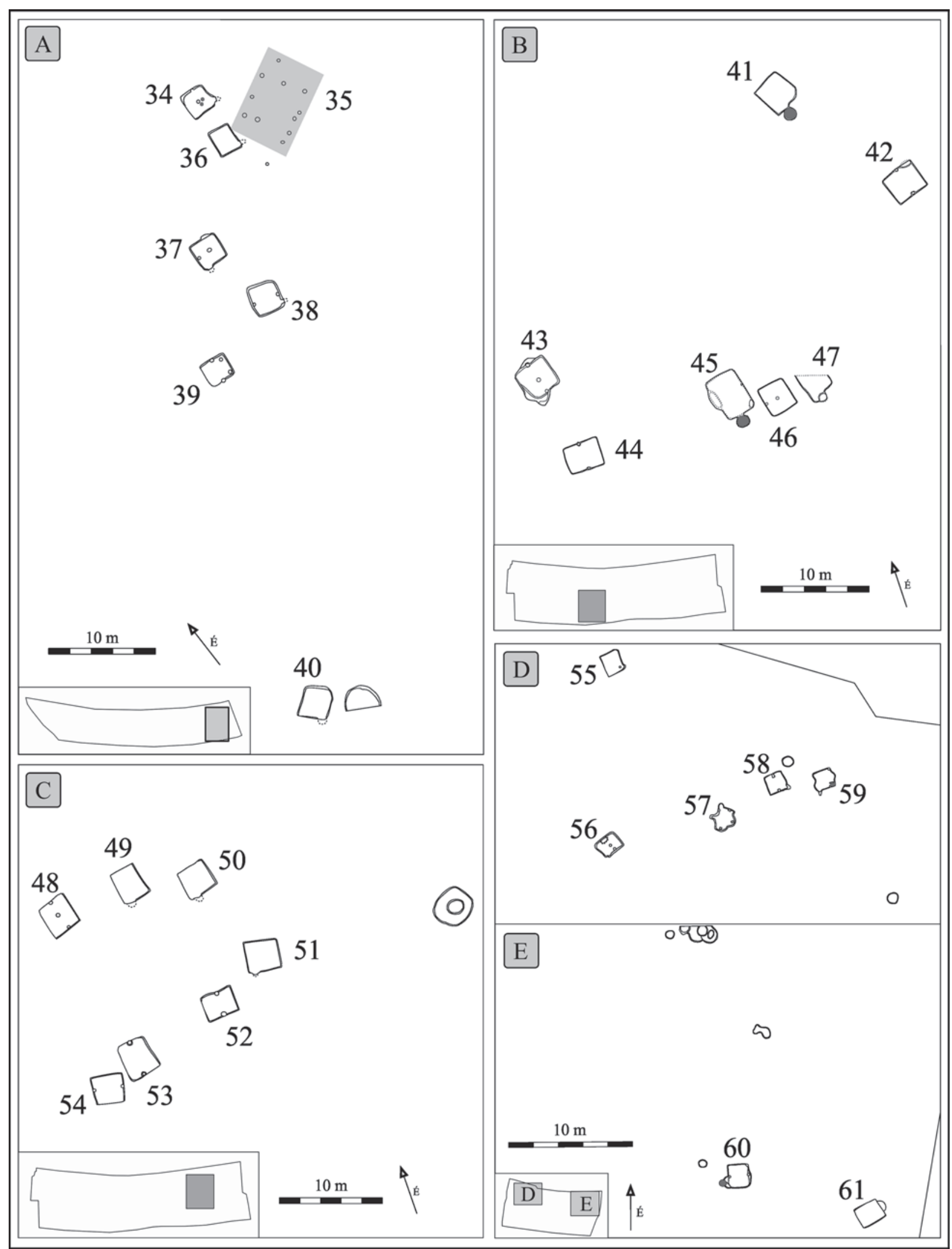

4. kép. A Rákóczifalva-Bagi-földek 5. lelőhelyen (A), a 8A lelőhely délnyugati (B) és északkeleti (C) területén, valamint a 08. lelőhelyen (D-E) feltárt avar kori települési objektumok

Fig. 4. Rákóczifalva-Bagi-földek, Avar period features of the site 5 (A), of the site 8A, uncovered in the site's south-western part (B), uncovered in the site's north-eastern part (C) and on the site 08 (D-E) 
oldal sarkának közelében (3. kép 02). Ennek az épületnek az érdekessége a két rövid oldal mentén végig megfigyelhető, lépcsőzetes kiszélesedés, padka. Alapterületük $7,6-11,7 \mathrm{~m}^{2}$, relatív mélységük 20-55 cm közötti. Két esetben ennél az épülettípusnál is meg lehetett figyelni egy-egy félköríves beásást a falban, az ÉK-i és DNy-i sarkoknál (3. kép 02, 06). Égett folt az egyik objektum padlójának közepén került elő (4. kép 46).

\section{6. típus: épületek négy oszlophellyel (2. kép 6)}

Csupán két téglalap alakú, egyenes falú veremház tartozik ebbe a csoportba $(4,4 \%)$, amelyeket az 5. és 8. lelőhelyeken tártak fel. Az egyikben a két hosszabb, É-i és D-i oldal közepén került elő egy-egy oszlophely, míg a másik kettó az ÉK-i és DK-i sarkok közelében helyezkedett el (4. kép 39). A másik épületben a négy sarokban volt egy-egy oszlophely (4. kép 57). Alapterületük 7,8 és 8,64 $\mathrm{m}^{2}$, relatív mélységük $40-80 \mathrm{~cm}$ közötti. Kemencére utaló maradványok nem kerültek elő.

\section{7. típus: épület öt oszlophellyel (2. kép 7)}

Egy a 2. lelőhelyen feltárt, lekerekített sarkú téglalap alakú, befelé enyhén szúkülő oldalfalú épület tartalmazott öt oszlophelyet, amelyek a hoszszanti tengely mentén helyezkedtek el, az épület két rövidebb oldala között (3. kép 05). A 11,24 m² alapterületú, $80 \mathrm{~cm}$ relatív mélységú gödör ÉNy-i oldalának D-i felén lépcsőzetes kialakítást lehetett megfigyelni, amely bejárathoz vezetó lépcső nyoma is lehet.

\section{8. típus: épület hat oszlophellyel (2. kép 8)}

Szintén egyetlen, a 2. lelőhelyen feltárt épület tartozik ebbe a típusba, amelynek három oszlophelye a hosszanti tengelyen, az épület belsejében került elő, kettő a hosszabb oldalak közepén, valamint a hatodik a DK-i sarok közelében (3. kép 17). Gödrének mérete $8,54 \mathrm{~m}^{2}$, relatív mélysége $51 \mathrm{~cm}$.

\section{9. és 10. típus: épületek tizenegy és tizenhárom oszlophellyel (2. kép 9-10)}

A 2. lelőhelyen egy téglalap alakú épület tizenegy cölöphelyet tartalmazott, amelyek közül kettó-kettó a hosszanti oldalak közepén, egy-egy a rövid oldalak közepén, egy-egy a négy sarokban, továbbá egy az egyik hosszanti oldal közepén, a másik két, itt található cölöphellyel háromszög alakot formázva került elő (3. kép 04). Padlója döngölt, kemencére vagy bejáratra utaló nyomot azonban nem lehetett megfigyelni.

A tizenhárom cölöphelyes épület szintén a 2 . lelőhelyen került eló, és szerkezeti elrendezése is hasonló volt az előzőhöz (3. kép 21; 5. kép 3). A cölöphelyek az épület falai mentén körben helyezkedtek el: a hosszú és rövid oldalak közepén is két-két, a négy sarokban egy-egy, valamint egy az egyik hosszanti oldal közepén, a másik két oszlophellyel háromszög alakot formázva. Az objektum ÉNy-i oldalának É-i felénél padkát találtak, amely talán az épületbe vezető lépcsőhöz tartozott.

Mindkét épület viszonylag nagyméretú volt: az egyik $11,4 \mathrm{~m}^{2}$, a másik $13,26 \mathrm{~m}^{2}$. Relatív mélységük 103 és $24 \mathrm{~cm}$.

\section{A szerkezeti elemek alapján rekonstruálható épülettípusok}

A lemélyített padlójú háztípus a Kárpátmedencében a kora vaskortól kezdve ${ }^{10}$ kisebb megszakításokkal a 13. századig általánosan, ${ }^{11}$ illetve elszórtan egészen a 19-20. század fordulójáig használatban volt. ${ }^{12}$ Maradványai általában könnyen megfoghatók régészeti módszerekkel; elterjedésükkel, használatukkal és rekonstrukciójukkal kapcsolatban számos tanulmány született. Az elsőként Méri István által megalkotott „ideális Árpád-kori házmodell”13 mellett különböző korszakok kutatóinak munkássága ${ }^{14}$ és az általuk tett kísérleti régészeti megfigyelések ${ }^{15}$ segítették a rákóczifalvi veremházak rekonstrukcióját. Fontos forrásként szolgáltak a néprajzi és antropológiai párhuzamok is. ${ }^{16}$ Ezek a tanulmányok egybehangzóan rávilágítanak a rekonstrukciós lehetőségek sokféleségére, ezen egyszerünek túnő épülettípus változatos kivitelezési lehetőségeire, valamint arra, hogy az ásatásokon talált maradványok milyen könnyen félreértelmezhetőek. ${ }^{17}$

10 CZIFRA 2006, 173

11 MÉRI 1952.

12 DÁм 1993, 133, 137, 144, 147.

13 MÉRI 1952.

14 A teljesség igénye nélkül néhány alapvető tanulmány a témában: BÓNA 1988; FODOR 1989; KOVALOVSZKI 2001; ŠALKOVSKÝ 2001; ŠALKOVSKÝ 2009; TAKÁCS 1993; TAKÁCS 2001; TAKÁCS 2002; TÍMÁR 2008.

15 Pleinerová 1986; TAKÁcs 1999, SABJÁn 1999; Zay 2013.

16 Köszönettel tartozom Tímár Lőrincnek, az ELTE Régészettudományi Intézete munkatársának, aki építészeti tudásával segítette munkámat.

17 A rekonstrukciók során gyakran elkövetett hibákról bővebben: TímÁr 2008, 400-402. 


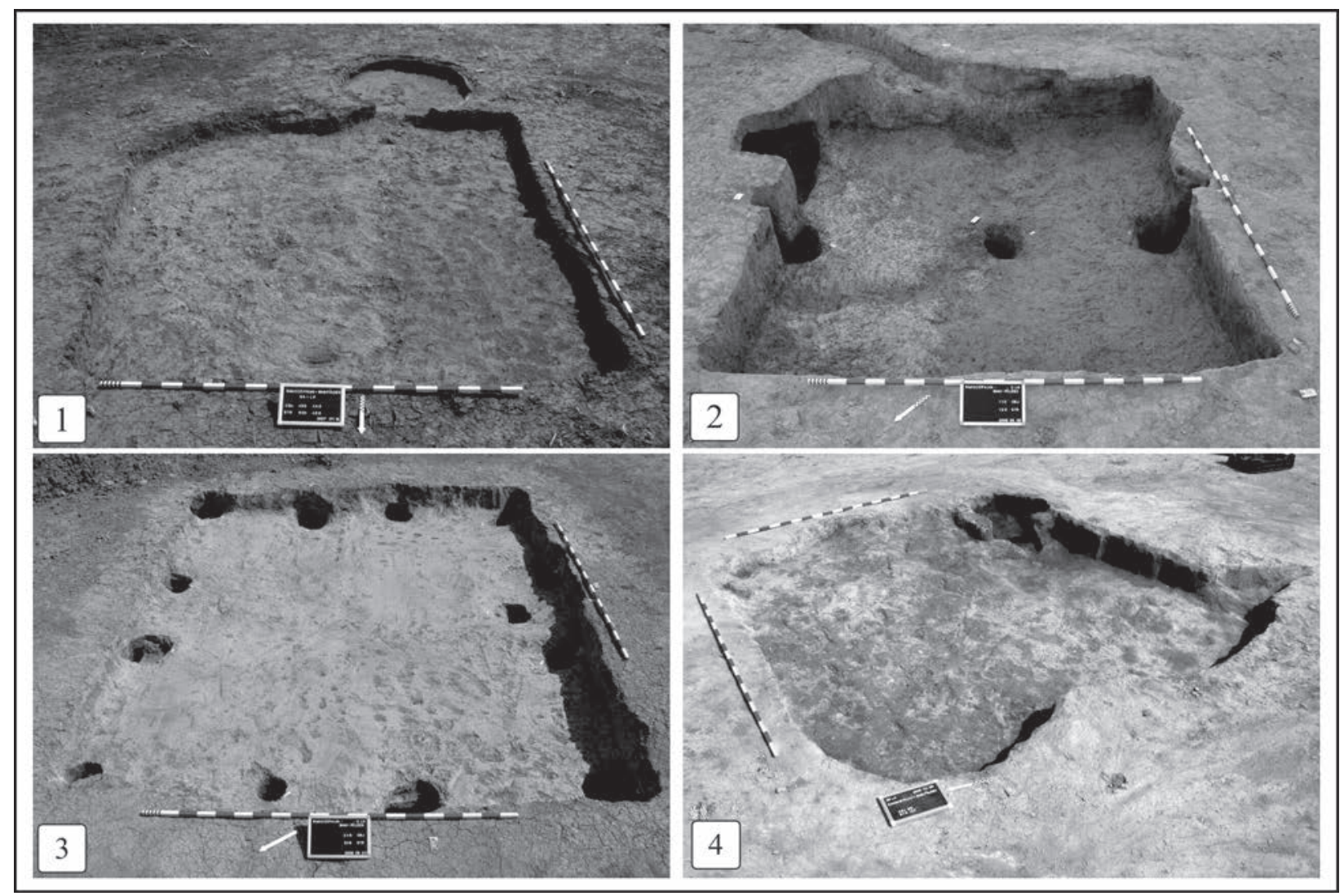

5. kép. Rákóczifalva-Bagi-földek. 1: 8A lelőhely 41. épület; 2: 2. lelőhely 18. épület; 3: 2. lelőhely 02. épület; 4: 8. lelóhely 59. épület

Fig. 5. Rákóczifalva-Bagi-földek. 1: Site 8A, Building 41; 2: Site 2, Building 18; 3: Site 2, Building 02; 4: Site 8, Building 59

Az alábbi tipológiai besorolás és rekonstrukciós lehetóségek a fenti tapasztalatokat figyelembe véve, de építészeti ismeretek nélkül készültek. A tipológia alapjául a tetőszerkezetet tartó, illetve néhány esetben a falat képezó oszlophelyek száma és elhelyezkedése, valamint az ezek figyelembevételével rekonstruálható épületforma szolgált. Az így keletkező négy csoport épületeihez tartozó egyéb jelenségek (bejárat, tüzelőberendezések, épületen belüli gödrök stb.) előfordulása vagy hiánya nem volt egységes, csupán egy csoportra jellemzó, de annyira változatos sem, hogy érdemes lett volna azokat külön tipológiai csoportokba sorolni.

\section{Külső tartószerkezettel ellátott épületek}

A legkevesebb következtetés az oszlophely nélküli és az egy oszlophelyet tartalmazó épületek (1. és 3a-d típus) egykori megjelenésével kapcsolatban vonható le, egy részüknek azonban minden bizonnyal a feltárt gödrökön kívül helyezték el a tartószerkezetét. ${ }^{18}$ Szerkezeti szempontból valójában nem alkotnak teljesen önálló tipológiai csoportot. Egykor vélhetően a legtöbb épülethez hasonló ágasfás-szelemenes tetóvel bírtak, némileg azonban eltérhettek azoktól a felszínre támaszkodó nyeregtetőből következő nagyobb belső tér és az ily módon körben keletkezó szélesebb padka miatt. Azoknál az épületeknél, amelyekben csupán egy oszlophely került elő valamelyik fal közepén (3c és 3d típus), elképzelhetö, hogy párja a másik oldalon, a gödrön kívül állt. ${ }^{19}$ A padló közepén található egyetlen oszlophely (3a típus) a külső tartószerkezet által tartott szelemengerenda alátámasztását, esetleg valamelyik ágas későbbi megújítását szolgálhatta

18 Megfontolandó ugyanakkor Sabján Tibor felvetése is, aki szerint sekély oszlophelyekbe és oszlophely nélküli épületek gödrébe is helyezhettek ágasfákat, méghozzá oly módon, hogy először rögzítették a tetőt tartó szerkezeti elemeket és a tetőt, és csak utána ásták ki az épületet, amikor már az egész szerkezet stabil és mozdíthatatlan volt: SABJÁN 1999, 139-140.

19 ŠALKOVSKÝ 2001, 27. 
(3. kép 03, 20, 33, 23; 4. kép 34, 37, 55). ${ }^{20}$ Az oszlophely nélkül elókerült épületek esetében az is elképzelhetó, hogy a lemélyített padlón kívülre, az egykori járószintre felmenó falat, boronafalat építettek. ${ }^{21} \mathrm{Ez}$ a rekonstrukciós lehetôség is csupán kevés esetben bizonyítható (3. kép 12, 13, 15, 27, 32; 4. kép 36, 40, 41, 47, 49-51, 59, 61). ${ }^{22}$

\section{Nyeregtetős épületek két vagy három ágassal}

Azok az épületek, amelyekben a hosszanti vagy rövid oldalakhoz igazodva egymással szemben két oszlophely vagy egy sorban három-öt oszlophely került eló (4a-c, 5a-b típus), nagy valószínúséggel ágasfás-szelemenes tartószerkezetú, nyeregtetős veremházak voltak (3. kép 02, 05, 06, 17, 19, 29; 4. kép 38, 39, 42-46, 48, 52-54, 56, 58, 60). A harmadik oszlophely szabálytalan elhelyezkedése ellenére idesorolható az az épület is, amelyben a két, hosszanti tengelyhez igazodó oszlophelyet egy harmadik egészíti ki az egyik sarok közelében (5c típus, 3. kép 02). ${ }^{23}$ Ehhez a csoporthoz tartozik az egyetlen öt oszlophelyes épület (7. típus). Oszlophelyei közül a két rövidebb oldal közepén található mélyebb volt, mint a hosszanti tengelyhez igazodó sorban elhelyezkedô három (3. kép 05). ${ }^{24}$ E szerkezeti csoport része egy veremház, amelyben a két hosszanti oldal közepén egy-egy mély oszlophely került elő, az épület két sarkához közel, egymással szemben pedig további kettő, amelyek azonban jóval sekélyebbek voltak (6. típus). Utóbbiak vélhetően nem a tetőszerkezethez tartoztak, vagy nem volt

20 TAKÁCs 2001, 34, 36-37. Az előbbire bizonyítékként szolgál az a balatonőszödi avar kori telepen megfigyelt épület, amelynek egyetlen, a belső tér közepén talált oszlophelyét a házbelsőn kívül, az épület hossztengelyéhez igazodva egy-egy további oszlophely egészítette ki: BELÉNYESY-MERSDORF 2004, 44, 54, 4. kép.

21 Néhány avar kori település oszlophely nélküli épületekkel: B. SZATMÁRI 1983, 73, 76, 16. kép; MADARAS 1986, 44; CSEH 1989, 35; MAdARAS 1991, 271; VADAY 1999, 235-236; IsTVÁNOVITS 2001, 167-170; HAJNAL 2009, 97. Oszlophely nélküli épületek, amelyek esetében hasonló rekonstrukciós lehetóségek merültek fel: TOMKA 1988, 38, 50; CSEH 1989, 38; TRUGLY 1996, 132; VIDA 1996, 326; LISKA 2004, 69; RÓZSA 2002, 117-118, 122-123; SZŐKE 2008, 213; BAJKAI 2012b, 408, 413; FODOR 2012, 712.

22 A szláv területeken előkerült, földbe mélyített épületek több mint fele nem tartalmazott oszlophelyet. Ezeket hasonló módon, az egykori járószintre támaszkodó, felmenő falú faházakként és oszlopvázas épületként rekonstruálják: ŠALKOVSKÝ 2001, 17, 20-22, 75; ŠALKOVSKÝ 2009, 275-276.

23 Bóna István több hasonló szerkezetú épületet figyelt meg Dunaújváros-Öreghegyen. Véleménye szerint a sarok közelében található harmadik oszlophelynek valamilyen alátámasztó szerepe lehetett: BóNA 1973, 67. További párhuzam: KovalovszKi 1975, 209.

24 Párhuzam a két oldalfal közepén elhelyezkedő oszlophelyek között sorakozó kisebb oszlophelyekkel ellátott épületre: BÓNA 1973, 47. jelentős statikai, csupán kitámasztó szerepük. Hasonló módon rekonstruálható egy hat oszlophellyel feltárt épület (8. típus, 3. kép 17): hosszanti oldalainak közepén egy-egy 59 és $72 \mathrm{~cm}$ mély oszlophely - vélhetően a nyeregtetót tartó oszloppár nyoma - került elő, továbbá a hosszanti tengelyben három, az épület DK-i sarkában pedig még egy sekély, 5-20 cm közötti oszlophely. Ez utóbbiak funkciója nem rekonstruálható, sekély voltuk miatt azonban aligha tartoztak az épület fó szerkezeti elemeihez.

Leggyakrabban ez, az épület hossztengelyében, de sok esetben a rövid oldal mentén leásott két ágasfás-szelemenes tetőszerkezettel, nyeregtetővel rekonstruálható épülettípus kerül eló avar kori telepek feltárása során. Az ebbe a csoportba sorolt rákóczifalvi veremházaknak az eddigi közleményekben így számos párhuzama található. ${ }^{25}$

\section{Cölöpváz-szerkezetes, felmenő falú épületek}

Sövény- vagy vesszőfonatos, felmenő falú épületként rekonstruálható két úgynevezett „sokcölöpös" épület, ${ }^{26}$ amelyek téglalap alakú gödrében a falak mentén, egymástól azonos távolságra tíz, illetve tizenkét cölöphely sorakozott (3. kép 04, 21; 5. kép 3). ${ }^{27}$ A tetó formájával kapcsolatban nem áll rendelkezésünkre információ. Az épületek többségétől eltérő módon itt úgynevezett koszorúgerendás sátortetőt is rekonstruálhatunk, ${ }^{28}$ amely a cölöpök közét kitöltő felmenő falakra

25 Trogmayer 1962, 3-4; BÓNA 1973, 67; B. SZATMÁRI 1983, 73; MADARAS 1986, 39-40; CSEH 1989, 35; MAdARAS 1991, 270; TAKÁCS 1996, 380, 382; TOMKA 1998, 46; VADAY 1999, 235; ŠALKOVSKÝ 2001, 22-27; TAKÁCS 2002, 280; BELÉNYESYMersdorf 2004, 44; Herold 2004, 65; KolozSI-SZAbÓ 2005, 176; HAJNAL 2009, 97-98, 104.

26 Köszönettel tartozom Dr. Takács Miklósnak, aki lektori véleményében Sabján Tiborra hivatkozva felhívta figyelmemet az épületek tartószerkezetével kapcsolatos terminológiai problémákra, miszerint az építészeti szakirodalom csak azokat a támokat nevezi cölöpnek, amelyeket levernek. Az előre megásott, felállított elemeket oszlopnak hívják. A régészeti szakirodalom gyakran következetlenül használja a "cölöphely", „cölöplyuk”, ,karólyuk”, „oszlophely” stb. szavakat, ami részben alighanem az eredeti épületszerkezet ismeretének hiányából, a rekonstrukciós nehézségekből fakad. Véleményem szerint az ágasfás-szelemenes tetőszerkezettel rekonstruálható veremházak esetében „oszlophelyekről”, míg a néprajzi irodalomban is ismert cölöpváz-szerkezetes, fonott falú épületek esetében „cölöpökről” és „,cölöphelyekról” beszélhetünk. Ld. SABJÁN-BUZÁs 2003, 27-31.

27 A sarkokban és az oldalak mentén elhelyezkedő cölöphelyek mélysége nem különbözött egymástól: 8-24 cm között mozogtak.

28 Az ott feltárt sok cölöphelyes épületek alapján TiszafüredMorotvapart avar kori telepen hasonló tetőszerkezetet rekonstruált Madaras László: MADARAs 1991, 271. 

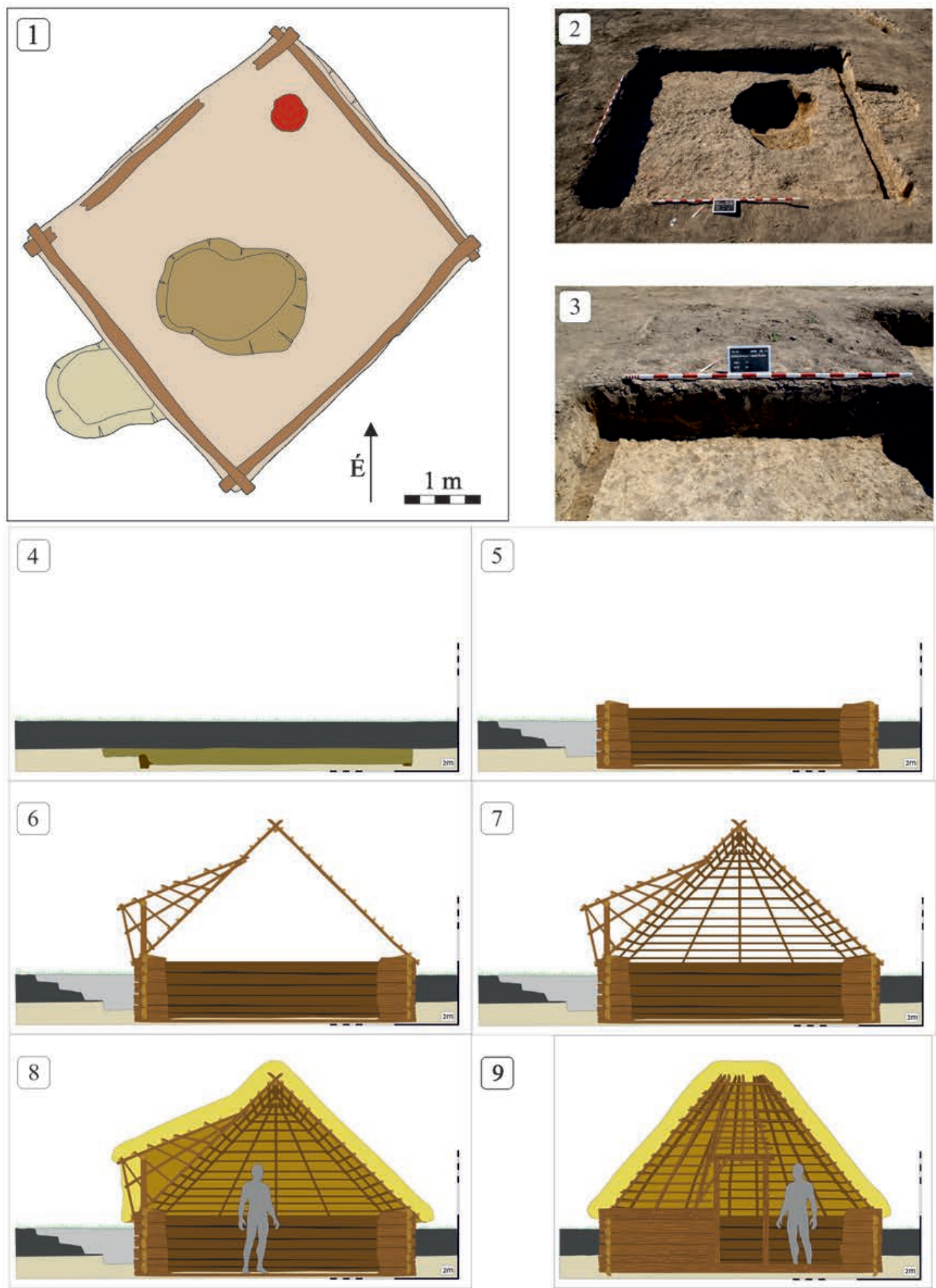

6. kép. Rákóczifalva-Bagi-földek 12. lelőhely, 33. épület. 1: alaprajz; 2: ásatási felvétel; 3: metszet; 4-9: az építési folyamat rekonstrukciója

Fig. 6. Rákóczifalva-Bagi-földek, Site 12, Building 33. 1: Plan; 2: excavation photo; 3: section; 4-9: reconstruction of the building process 
támaszkodott, ${ }^{29}$ ugyanakkor a nyeregtetős megoldás is elképzelhető. ${ }^{30}$

Mindkét ÉNy-DK-i tájolású épület esetében megfigyelhető, hogy a DNy-i hosszanti oldal közepén lévő két cölöphely között, azokkal háromszög alakzatot formázva még egy ismeretlen funkciójú cölöphely került elő. Szintén mindkét épületre jellemző az átlagos 9,5 $\mathrm{m}^{2}$-t meghaladó, viszonylag nagy alapterület (11,4 és 13,26 m²). A tizenhárom cölöphelyes épületmaradvány ÉNy-i sarkánál a feltárók padkát figyeltek meg: ez a bejárat nyoma lehetett, amelyet minden bizonnyal két cölöp között, a sövényfal kihagyásával oldottak meg. A két épület relatív mélysége igen eltérő volt: míg az egyik gödör alja csupán 24 cm-rel, a másik 103 cm-rel mélyedt a humuszolt felszín alá.

Mivel ez az épülettípus sokáig csupán az egykori alemann-bajor településfeltárásokból volt ismert, a Kárpát-medencében pedig a Tisza-vidéki gepidáknál és főként Erdély területén fordult elő, a kutatás sokáig észak-európai („germán”) típusú házként tartotta számon a hagyományosan sokcölöpösnek nevezett, felmenó falú épületeket. ${ }^{31}$ Ha nem is nagy számban, de szláv telepekról szintén régóta ismert több párhuzama. ${ }^{32}$ Mára azonban több olyan avar kori teleprészlet ismert, ahol előfordultak, vagy éppen domináltak azok a veremházak, ahol a gödör falai mentén körben legalább hat cölöphely került elő. ${ }^{33}$

29 TAKÁCS 2002, 285.

30 ŠALKOVSKÝ 2001, 87, 89.

31 ŠALKOVSKÝ 2001, 33; ŠALKOVSKÝ 2009, 277; TAKÁCS 2002, 278; B TÓTH 2006, 48; HAJNAl 2009, 92; BAJKAI 2012a, 16; DONAT 1988 21-22. Néhány párhuzam népvándorlás kori germán településekról: HoREDT 1979, 91, Abb. 40; 100; SzABÓ 1978, 61-62, 64 3. ábra; SKRIBA-SÓFALVI 2004, 121-132; B. ТÓTH 2006, 48, 56-69. Részletes irodalmi gyújtés és áttekintés a háztípussal kapcsolatban: GUYAN 1952, 180, 191, Abb. 68, 192, Abb. 69 195, Abb. 70; SKRIBA-SÓFALVI 2004, 145, 147.

32 KRASKOVSKÁ 1961, 399; KRÜGER 1964, 44, Abb. 2, 45; BÓNA 1973, 67; PleinerovÁ 1979, 629-630, 633; RUTTKAY 2002, 264, 266; ŠALKOVSKÝ 2001, 29, 33; ŠALKOVSKÝ 2009, 276-277; ŠALKOVSKÝ 2011, 422.

33 Dunaújváros-Öreghegy lelőhelyen csupán egy épület volt, amelynek falai mentén kilenc oszlophely sorakozott: BóNA 1973, 28-29. Az épület gödrében körben kisebb oszlophelyekkel feltárt épület került elő Tatabánya-Alsógalláról: B. SZATMÁRI 1983, 73. Kompolt-Kistér lelőhelyen egy épületben találtak hat oszlophelyet; ezek és a faltapasztás darabjai alapján felmenő falakra lehetett következtetni: VADAY 1999, 234235. Avar kori, három vagy négy felmenő falú, koszorúgerendás tetővel ellátott épületeket először Madaras László rekonstruált három, Tiszafüred-Morotvaparton feltárt avar kori teleprészlet alapján: MADARAS 1986, 44; MADARAS 1991 271. Két oszlopváz-szerkezetes, felmenő falú épületet rekonstruáltak Balatonőszöd-Temető-dúlő lelőhelyen is: BELÉNYESI-MERSDORF 2002, 44, 55, 6-7. kép. A kardoskúti lelőhely két avar kori épületében a négy sarokban és a rövidebb oldalak közepén voltak nagyobb oszlophelyek, valamint

\section{Boronaház}

Rákóczifalva 12. lelőhely egyik épületének esetében a lemélyített gödör falai mentén húzódó árkok alapján bizonyos, hogy ide egy talpgerendát helyeztek (3. kép 33; 6. kép 1-3). Az árkok végei metszették egymást, ami azt bizonyítja, hogy itt csapolták, helyezték egymásra a talpgerendákat. ${ }^{34} \mathrm{~A}$ gerenda pontos méretére és formájára a szögletes, 19-22 cm széles árok alapján nem következtethetünk, hiszen az csak a gerendának kiásott hely, amelynek szélessége tehát a gerenda maximális vastagsága. A felhasznált fát meg is munkálhatták, mivel avar kori kutakból ismerünk ácsolt tölgygerendákat. ${ }^{35}$ Egyszerú rönköket is használhattak, a faanyag legjobb kihasználására azonban a hosszában hasított félrönk volt alkalmas. ${ }^{36}$

A talpgerendán álló felmenő fal egyik lehetséges változata a függóleges karóvázas, tapasztott sövény- vagy vesszőfal. ${ }^{37}$ E megoldás ellen szól a paticsdarabok hiánya az épület égett betöltésében és a már említett csapolási nyom. ${ }^{38}$ A keresztben egymásra helyezett gerendák azt bizonyítják, hogy a vizsgált épület egymásra fektetett gerendákból kialakított, boronafalú épületként rekonstruálható. A boronafal kialakításának egyik lehetséges módja, hogy függóleges tartóoszlopokat helyeztek a földbe, majd ezek közé fektették a falat alkotó rönköket: ez a zsilipelt boronafal. ${ }^{39}$

ezek között több kisebb lyuk: RózSA 2002, 117-118, 122, 135, 3. kép. Kölked-Feketekapu lelőhelyen nagy számban, 16\%-os arányban fordultak elő hat- és nyolcoszlopos épületek, amelyek falszerkezete is nagy valószínúséggel rekonstruálható a megmaradt agyagtapasztás-darabok alapján: HAJNAL 2009, 98-99, 105-112. Hajdúnánás-Mácsi-dúlő lelőhelyen az épületek többségét sokoszlopos elrendezés jellemezte. Leggyakrabban hat-tíz oszlophelyet tartalmaztak, amelyek alapján publikálójuk felmenő falú épületeket rekonstruált: BAJKAI 2012a, 16-17; BAJKAI 2014, 31, 3. kép, 35.

34 ISTVÁNFI 1997, 146.

35 Például: Stadler-Herold 2003; TOMKA 2003.

36 Pleinerová 1986, 121.

37 DÁM 1993, 139; FODOR 1994, 423; ISTVÁNFI 1997, 148-150; ŠALKOVSKÝ 2001, 72, Abb. 40.5, 75; TARI 2001, 162-163. Egy földfelszíni, talpgerendás, gerendavázas falú hosszúházat, valamint egy szintén földfelszíni, oszlopszerkezetes épületet rekonstruált Hajnal Zsuzsa Kölked-Feketekapu lelőhelyen: HajNAL 2009, 92-95. Hajdúnánás-Mácsi-dúlő lelőhelyen két földbe mélyített, alapárkos, oszlopszerkezetes épület került elö, amelyeket a lelóhelyen talált paticsdarabok értékelése alapján oszlopokkal, ágakkal merevített, agyagfalú épületekként lehetett rekonstruálni: BAJKAI 2012a, 17-19; BAJKAI 2014, 35.

38 A paticsdarabok hiánya alapján arra is következtethetünk, hogy a boronák közét, réseit nem tapasztották ki agyaggal, ugyanakkor más szerves anyagot, például mohát használhattak erre a célra: HOFFMANN 1992, 17, 19; TARI 2001, 177.

39 Pleinerová 1986, 119-127; HofFMANN 1992, 15; ISTVÁNFI 1997, 146-147; ŠALKOVSKÝ 2001, 72, Abb. 40.6-7; TARI 2001, 177; SABJÁN-BUZÁs 2003, 14; ŠALKOVSKÝ 2011, 421. 
Másik, általánosabb és egyszerúbb módja, hogy nem használtak tartóoszlopokat, a csapolt gerendákat csupán keresztben egymásra helyezték az épület sarkainál (6. kép 4-5).40

Bár nem tudjuk, milyen magas volt a felmenő fal, a gödörházak kialakításának bizonyára egyik lényeges szempontja lehetett, hogy a lehetó legkevesebb építőanyag és a lehető legkisebb energia befektetésével készüljenek. ${ }^{41}$ Ezért feltételezem, hogy a boronafal nem volt sokkal magasabb, mint az egykori külső járószint. Ennek abszolút magassága nem ismert. Az épület relatív mélysége azonban 30-40 cm volt, felette pedig $50 \mathrm{~cm}$ vastag humuszréteg feküdt az ásatás kezdetén, tehát legfeljebb $90 \mathrm{~cm}$ mélyen lehetett az épület alja. Ezeket figyelembe véve körülbelül egyméteres falmagassággal és 45 fokos tetódőlésszöggel számolva több mint kétméteres, kényelmes belmagasságot kapunk (6. kép 6).

A legkevesebb adat a tetó szerkezetének rekonstruálásához áll rendelkezésre: nyereg- és sátortető egyaránt elképzelhető. Mivel azonban taréjszelement tartó ágasfára utaló oszlophely nem került elő, valószínúbb, hogy egykor sátortető fedte az épületet. Így a taréjszelement négy oldalról támasztották a szarufák - ez stabil önhordó rendszer statikailag jóval biztosabb, mintha csak a nyeregtető két oldalán lévő szarufák támogatnák a taréjszelement (6. kép 7). ${ }^{42}$ Elképzelhetó, hogy a nyeregtetót tartó ágasfát a talpgerendába állították. Ebben az esetben azonban ezek kizárólag az ÉNy-DK-i oldalon állhattak, mivel a DNy-i oldal közepénél található, lépcsőszerú lemélyítés alapján ott egy ajtó lehetett. Sátortetó esetén a szarufák alját tartó talpszelemenként a fal legfelső gerendája szolgált, amelynek némileg ki kellett emelkednie a földból, hogy megakadályozza a tető felázását.

A tető dőlésszögének megrajzolásához az itteni klímának leginkább megfelelő, 45 fok közeli dőlésszöget használtam. ${ }^{43} \mathrm{~A}$ tető rekonstrukciójához figyelembe vettem azt a már említett, sekély gödröt, amely az épület DNy-i fala mentén, annak közepén helyezkedett el, és vélhetően földbe vájt lépcső legalsó fokának maradványa. Ezt támasztja alá tájolása, amelynek köszönhetően a lehetô legtöbb fény juthatott be az épületbe, valamint az a tény, hogy a tárgyalt épület mellett álló másik épületnél is megmaradt egy ilyen gödör, szintén a DNy-i oldalon. Az ajtó kialakításához a boronafalat meg tudták bontani, illetve a tető

40 HofFManN 1992, 17; ŠALKOVSKÝ 2001, 72, Abb. 40.8-9.

41 TÍMÁr 2008, 400.

42 HofFMANN 1992, 20; ŠALKOVSKÝ 2001, 89.

43 Pleinerová 1986, 109; SABJÁN 1999, 131, 141; ŠAlKOVSKÝ 2001, 74, 90; Tímár 2008, 401, Fig. 5. megbontása, a lépcső fölé történő meghosszabbítása vagy egy háromszög alakú, nyeregtetős gádor ${ }^{44}$ kialakítása sem igényel jelentős építészeti ismereteket (6. kép 8-9).

$\mathrm{Az}$ épület északi sarkában kirajzolódó kerek, égett folt vélhetően tüzelőhelyként funkcionált (6. kép 1). Habár ez ellen szólhat a faépület gyúlékonysága - hiszen a vizsgált épületben nem kerültek elő tapasztás maradványai, amely a kicsapódó lángoktól védhette volna a falat -, számos néprajzi példa igazolja, hogy egy kicsi, szabadon álló tüzelőhelyet gyúlékony kunyhóban is kialakíthattak, és esetleg kővel rakták körbe, hogy a tŭz ne terjedhessen. ${ }^{45}$

A 8. lelóhelyen feltárt egyik épület esetében szintén elképzelhetó, hogy egykor felmenő boronafallal rendelkezett, mivel négy sarkában egyegy, egymástól azonos távolságra elhelyezkedő, négyzet alakú oszlophely volt (4. kép 57). Az egykori tartószerkezet ezek alapján úgy képzelhető el, hogy a sarkokba egy-egy gerendát, úgynevezett gyámfát helyeztek, és ezek közé, a sarokoszlopok bevájásával rögzítették a négy oldalfalat alkotó vízszintes gerendákat. Ez a fent már említett zsilipelt boronafalas megoldás, ${ }^{46}$ amely avar kori telepekről csupán kis számban ismert, mindig hasonló módon rekonstruált. ${ }^{47}$ Mivel azonban a tárgyalt épületmaradvány falai szabálytalanok voltak, a boronafalas megoldás csupán abban az esetben képzelhetố el, ha az épület eredetileg téglalap alakú volt, a feltárt forma pedig későbbi bolygatás eredményeképpen jött létre.

Faszerkezetú, illetve egyéb felszíni épületekre a kutatás sokáig szinte csak késóbbi településekról ismert bizonyítékokat. ${ }^{48}$ Ugyanakkor avar kori épületek vizsgálata során is számos szakember felvetette felmenő falú, kevés maradandó nyomot hagyó háztípusok létezésének lehetőségét - például az oszlophely nélküli, földbe mélyített épületek kapcsán. ${ }^{49} \mathrm{~A}$ boronaházakat a kuta-

44 SABján 1999, 138, 146.

45 SABJÁN 1999, 134-135.

46 Ld. 38. lábjegyzet.

47 Az eddig közölt avar kori telepeken viszonylag ritkán kerültek elő épületmaradványok négy, sarokban elhelyezett oszloppal, amelyeknél szintén cölöpváz-szerkezetes, felmenó falat rekonstruáltak: CSEH 1989, 35; BELÉNYESY-MERSDORF 2002, 44.

48 Például: HoRvÁth 1968; HoRvÁth 1971, 65; LÁSZló 1978, 74-75; BENKŐ 1984, 31; Cs. SÓs 1984, 70, 241-242; FODOR 1989, 26; LÁZÁr 1998, 75-76; FODOR 1994, 42; ILON 1996; TARI 2001, 163-174. Egy további párhuzam és az ilyen típusú épületek lelőhelyeinek részletes gyưjteménye: TAKÁCS 2001, 26-27.

49 K. Csilléry 1982, 71; MADARAS 1986, 44; TOMKA 1988, 38, 50; CSEH 1989, 38; SZŐKE 1992, 136; TAKÁCS 1996, 380; TRUGLY 1996, 132; VIDA 1996, 326; LISKA 2004, 69; SZŐKE 2008, 213; BAJKAI 2012b, 408, 413; FODOR 2012, 712. 
tás korábban a szláv népességhez kötötte, ${ }^{50}$ mivel északi, mai szlovákiai és fóként nyugati szláv területeken feltárt, kora középkori telepeken valóban több objektum képviselte ezt a háztípust. ${ }^{51}$ Magyarország területéről Váradi Adél publikálta a bemutatott objektumhoz hasonló elsó épületeket. ${ }^{52}$ A Nagyút közelében feltárt két, „sarkos, alapárkos házként" jellemzett épületról azonban nem jelent meg olyan rajz vagy fotó, amely alapján nagy biztonsággal párhuzamba lehetne állítani a rákóczifalvi épülettel. ${ }^{53}$ Analógiaként említhető egy a 8. századra keltezett, Csorna-Mocsáridúlő lelőhelyen feltárt, földbe mélyített padlójú, két rövidebb oldalán két-két oszlophellyel ellátott épület, amelynek oldalait gerendából vagy deszkákból építették fel. ${ }^{54}$ A rákóczifalvihoz szintén hasonló szerkezetú lehetett az a NagykállóHarangod lelőhelyen kibontott épület, ahol a falaktól $20 \mathrm{~cm}$-re, azokkal párhuzamosan függóleges tapasztást figyeltek meg, amely legnagyobb valószínúséggel fafalazat tapasztásaként rekonstruálható. ${ }^{55}$

\section{Cölöpszerkezetes, felszíni épületek}

A változatos szerkezetú, földbe mélyített padlójú épületek mellett feltártak számos olyan, cölöphelyek által kirajzolt objektumot, amelyek különböző funkciójú, cölöpökön nyugvó felmenő falú építményként rekonstruálhatók. Ezek egyetlen objektum kivételével a 2. lelőhelyen helyezkedtek el, ahol egy lazább és két súrúbb, egymástól 60-80 méterre lévő objektumcsoport különíthetó el a feltárt terület ÉNy-i, középső és DK-i részén.

A DK-i csoportot öt földbe mélyített épület, néhány gödör, egy ovális és egy L alakú árok mellett egy öt cölöphely által kirajzolt jelenség alkotta (3. kép B). Ez utóbbi a mellette lévő két épülettel azonos, Ny-K-i tájolású, és egy körülbelül 6×3 méteres területet fog közre (3. kép 14).

A lelőhely közepén sûrúsödő objektumcsoportban az öt földbe mélyített épület és a gödrök mellett feltártak egy tizennégy, egymástól azonos távolságban lévő, négyzetes cölöphely által kirajzolt, téglalap alakú, 4,4×6,6 méteres, ÉNy-DK-i

50 FODOR 1994, 426.

51 KraskovsKá 1961, 399; PleINEROVÁ 1986, 119-136; ZÁBOJNIK 1988, 407; HABOVŠTIAK 1989, 10; BRATHER 2001, 98, 103 ŠALKOVSKÝ 2001, 57; ŠALKOVSKÝ 2011, 421. Hoffmann Tamás a boronaházak áttekintése kapcsán hangsúlyozza a háztípus földrajzi összefüggéseit, és az erdőövezet jellegzetes építményének tartja: HOFFMANN 1992, 17-20.

52 VÁRAdI 2000.

53 VÁRAdi 2000, 130.

54 TOMKA 2004, 240.

55 Gergely s. a. tengelyú területet (3. kép 01). A struktúra érdekessége, hogy a DK-i oldalát kirajzoló két középső cölöphely között, azoktól befelé egy további cölöphely helyezkedett el, az előző kettővel háromszög alakot kirajzolva, hasonlóan az ugyanezen a lelőhelyen napvilágra került, földbe mélyített, sokcölöpös vagy cölöpváz-szerkezetes épületekhez. A DK-i oldal vonalában, annak meghosszabbításában két további cölöphely tartozott a tárgyalt objektumhoz. Ennek közelében, ÉNy-i irányban további négy felszíni építmény nyoma figyelhető meg: egy 13, egy 19, egy 18 és egy 8 cölöphelyből álló objektum, amelyek rendeződése azonban szabálytalan, nehezen értelmezhetó (3. kép 7, 8, 10, 11).

A 2. lelőhely ÉNy-i végében a hat, nagyjából azonos tájolású, földbe mélyített padlójú épület, a gödrök és egy L alakú árok mellett a terület nagy részét cölöphelyek által jelölt, nagy kiterjedésú építmények fedték. A legnagyobb egybefüggő területen rendeződő cölöphely-rendszer két nagyméretǔ, 25-35 négyzetes cölöphely által kirajzolt, téglalap alakú, ÉK-DNy-i tájolású struktúrát mutat (3. kép 24; 7. kép 1). A DK-i, nagyjából 11×16 méteres objektum belsejét két ÉNy-DK-i és egy ÉK-DNy-i irányú cölöpsor több helyiségre osztja. Közvetlenül kapcsolódik az azonos méretú, ENy-i struktúrához, amelyet szintén tagol egy ÉNy-DK-i oszlopsor, de egy nagyobb üres területet is magában foglal. Ettól néhány méterre DK-i irányban egy tíz cölöphelyból álló, trapéz alakú, 10×8 méteres objektum volt, amelynek DK-i sarkát nem találták meg (3. kép 25). Ettől ÉNy-ra bontottak ki 26 cölöphelyet, amelyek egy ÉÉK-DDNy irányú, 5×20 méteres, téglalap alakú épületet rajzolnak ki (3. kép 26; 7. kép 2). A téglalap DDNy-i rövid oldalán hiányoznak a cölöphelyek, ÉÉK-i oldala mellett viszont további, szabálytalanul elhelyezkedő cölöphelyek sorakoznak, amelyeknek a tárgyalt objektumhoz való tartozása bizonytalan. Egy méretben és formában is igen hasonló, egyik rövid végén szintén nyitott, azonban DNy-EK-i tengelyú objektumot rajzol ki a lelóhely ÉNy-i végén található 19 oszlophely (3. kép 30; 7. kép 3). DNy-i oldala mellett elókerült néhány szabálytalanul szóródó cölöphely, amelyek szintén nem köthetők biztosan a bemutatott objektumhoz. Valamilyen felszíni építmény nyoma lehet az az L alakba rendeződó négy cölöphely is, amelyek a fenti objektumoktól DNy-i irányban helyezkedtek el (3. kép 28).

A 5. lelőhelyen feltárt hat, földbe mélyített épület mellett egy azonos, ÉNy-DK tájolású, $4 \times 4$ méteres építmény nyomát rajzolta ki tizenkét kerek és ovális alakú cölöphely, amelyek közül ki- 


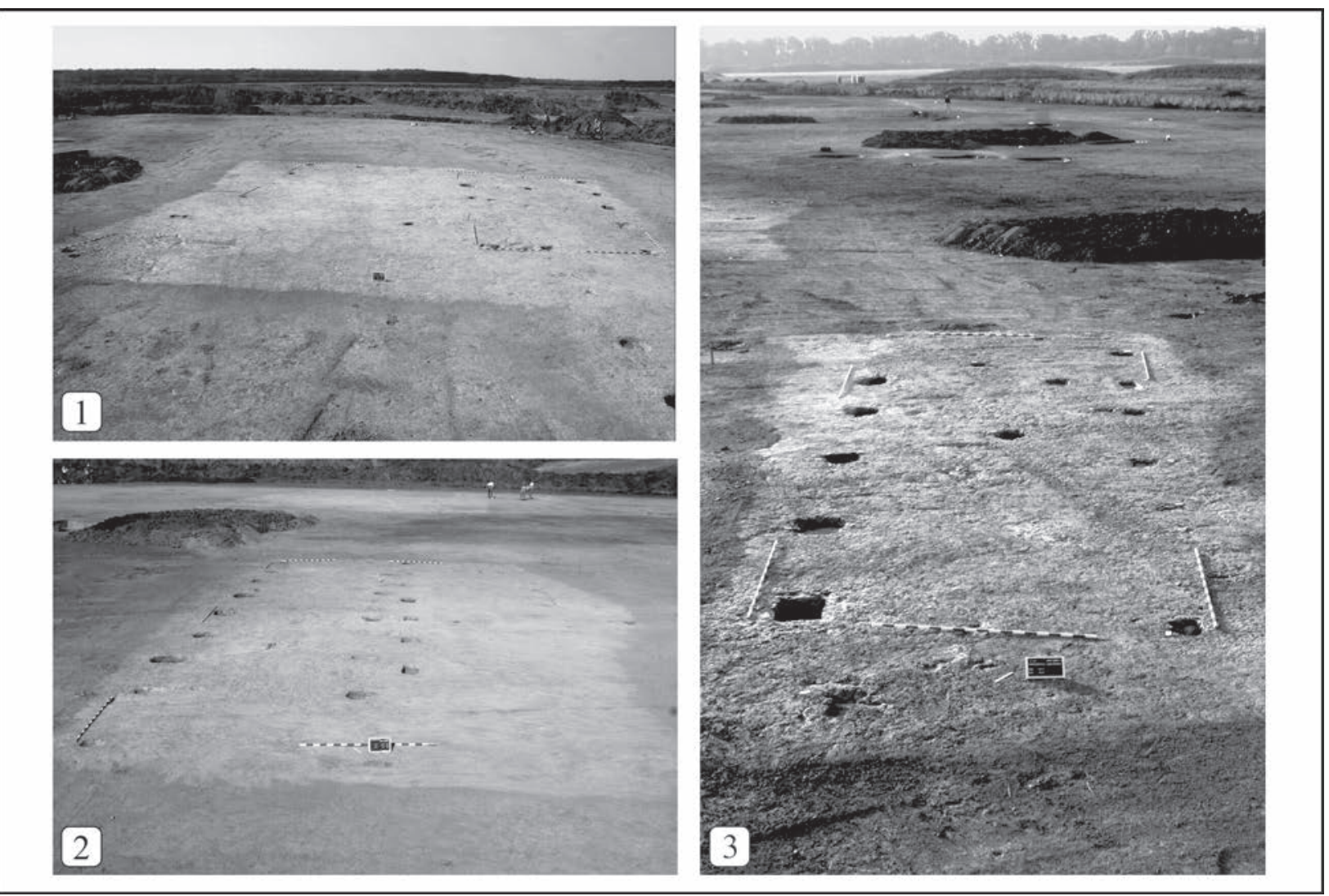

7. kép. Rákóczifalva-Bagi-földek 02. lelőhely. Cölöpszerkezetes felszíni építmények nyomai. 1: 05. objektum; 2: 07. objektum; 3: 11. objektum

Fig. 7. Rákóczifalva-Bagi-földek, Site 02. Remains of above-ground, post-framed structures. 1: Feature 05; 2: Feature 07; 3: Feature 11

lenc négyzet alakban helyezkedett el, egy az É-i fal, kettó további pedig a D-i fal vonalában, azok K-i és Ny-i meghosszabbításaként (4. kép 35).

\section{Rekonstrukciós lehetóségek}

A bemutatott, cölöphelyek által kirajzolt, egykor bizonyosan felszíni struktúrák rekonstruálását megnehezíti az a tény, hogy a markológéppel végzett humuszolás során több hozzájuk tartozó, sekélyebb cölöphely eltúnhetett. A megmaradó objektumok mindegyike igen sekély volt, mélységük többnyire 5-10 cm között mozgott, és nem haladták meg a $25 \mathrm{~cm}$-t. Szintén nehézséget jelent, hogy avar kori telepekról eddig csupán igen kevés hasonló szerkezetú épület ismert. A rákóczifalvi cölöphelyek betöltésében talált kevés avar kori kerámia mellett recens voltukat kizárja, hogy tájolásuk és elhelyezkedésük igazodik a többi avar kori települési objektumhoz. Építésüknél egyértelmúen figyelembe vették azokat, tehát a legtöbb objektummal azonos időben kellett állniuk.
A kisebb, szabályosan rendeződő cölöphelyek által jelölt jelenségek esetében elképzelhető, hogy azok lakófunkcióval bírtak, és a rákóczifalvi cölöpváz-szerkezetes, földbe mélyített épületekhez (9. és 10. típus) hasonló, vesszőfonatos, tapasztott felmenó fallal rendelkeztek (3. kép 01, 14, 28; 4. kép 35). ${ }^{56}$ Két hasonló, de kisebb épületet Szolnok-Zagyvapart lelőhelyen lehetett rekonstruálni, ahol az egykori földfelszíni épületek mellett földbe mélyített épületek szintén nagy számban előfordultak. ${ }^{57}$ Két további, egy 5,5 és egy 6,6 méter széles, oszlopszerkezetes épület részleteit bontották ki Kölked-Feketekapu lelöhelyen. ${ }^{58}$ Egy a rákóczifalvi objektumokhoz méretében is hasonló, oszlopszerkezetes épület maradványai ismertek Zillingtal lelőhelyről. A publikáló szerint a házként és karámként egyaránt értelmezhető, 4,4×5,5 méteres épületet egymástól 70-80 cm-re elhelyezkedő oszlophelyek rajzolták ki. ${ }^{59}$

\footnotetext{
56 HOFFMANN 1992, 14.

57 CSEH 1989, 33-34.

58 HAJNAL 2009, 95-96.

59 Herold 2010, 107, 110.
} 


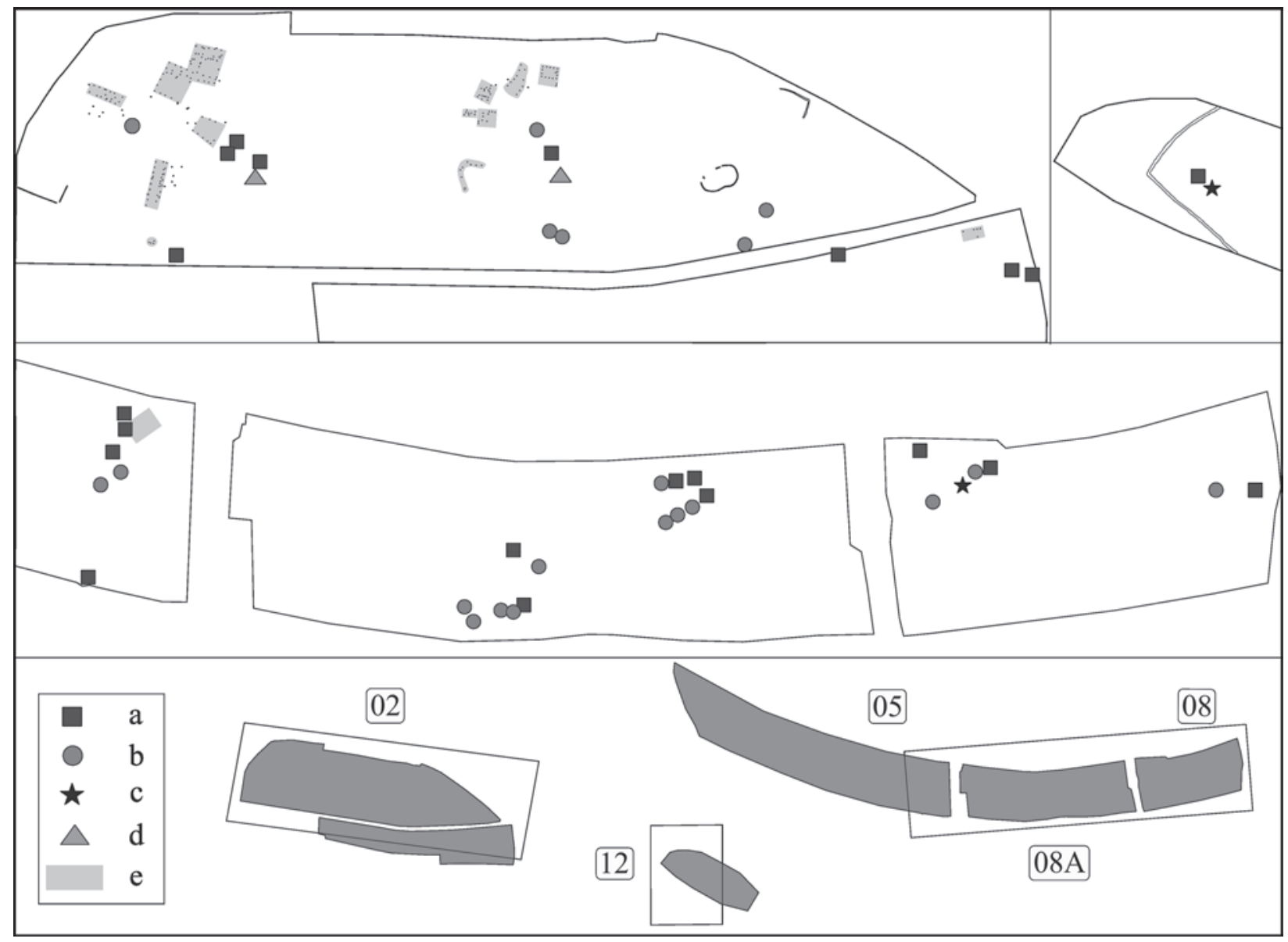

8. kép. A különböző épülettípusok elterjedése a lelőhelyen: földbe mélyített padlójú épületek (a: külső tartószerkezet/felmenő fal, b: ágasfás-szelemenes tetőszerkezet, c: boronafal, d: cölöpszerkezetes, felmenő fal) és cölöpszerkezetes, földfelszíni építmények (e)

Fig. 8. Distribution of different building types on the site: sunken buildings (a: external supports/vertical walls, b: a roof structure of purlins supported by forked ridge poles, c: log cabin-like buildings, d: post-framed structures with upright walls) and above-ground, post-framed structures (e)

A rákóczifalvi lelőhelyen feltárt, nyújtott téglalap alakú, 5×20 méteres nagyságban kirajzolódó építmények esetében sem zárható ki, hogy azok az észak-európai típusú (úgynevezett "germán") hosszúházakhoz vagy csarnokházakhoz hasonlóan lakóépületként is szolgáltak. ${ }^{60}$ Az erre utaló padló és tüzelőhely egyaránt elpusztulhatott ilyen közel a jelenlegi felszínhez (3. kép 26, 30; 7. kép 2).

A legnagyobb területet fedő, egybefüggő oszlopszerkezetes struktúra (3. kép 24; 7. kép 1) vélhetően karámrendszerként értelmezhetô. A többi, nagyobb és szabálytalanabb objektum szintén gazdasági épületként rekonstruálható: istállók, szélfogók vagy terelőfalak lehettek.

A földfelszíni épületek kapcsán érdemes figyelembe venni a rövidebb, L vagy félkör alakú árkokat is, amelyek egykor szintén tartozhattak fel-

60 GuYan 1952, 182, 196, Abb. 71; MesterháZy 2002, 85. színi jelenségekhez - nád- vagy sövényfalakhoz, sáncokhoz, enyhelyekhez $-{ }^{61}$ de egyéb, mára nyomtalanul eltúnt épületek helyét is jelölhetik (3. kép 16, 18, 31). ${ }^{62}$

\section{Következtetések}

A Rákóczifalva-Bagi-földek lelőhelyen feltárt avar kori épületek többségét a kutatás „hagyományos, szabályos" háztípusként tartja számon: négyzetes formával, földbe mélyített padlóval és ágasfás-szelemenes, nyeregtetős szerkezetre

61 MÉRI 1962; SZABó 1975; ISTVÁNFI 1997, 226-227.

62 A telepkutatásban már többször felmerült az a lehetőség, hogy bizonyos árkok egykor felszíni épületeket határoltak: KovalovszKi 1975, 207, 209. Az árkok - és akár egyéb, ismeretlen rendeltetésú objektumok - funkciómeghatározásának egyik lehetséges módja a talajok foszfátelemzése: LASZLOVSZKY 1982; RENFREW-BAHN 1999, 286. 
utaló oszlophelyekkel. ${ }^{63}$ A negyvenöt földbe mélyített padlójú épület közül azonban tizennégynél nem került elő oszlophely. Ezeknél a gödrön kívüli ágasfás-szelemenes, nyeregtetôs szerkezet vagy másfajta, felmenő fal egyaránt feltételezhető. Emellett négy földbe mélyített épület felmenő fallal rekonstruálható; kettó boronafallal, kettó pedig cölöpváz-szerkezetes sövényfallal. Avar kori településeken mostanáig ez utóbbi épülettípusoknál is ritkábban kerültek elő földfelszíni, cölöpszerkezetes építmények, amelyek Rákóczifalván szintén aránylag nagy számban fordultak elő. Az idesorolható tizenkét, sekély cölöphelyek által kirajzolt építmény közül méret és forma alapján hat esetben merülhet fel, hogy az épületet lakásként (is) használták (8. kép).

A sekély cölöphelyek csekély leletanyaga, illetve a lelőhely kerámiaanyagának viszonylag homogén volta miatt a biztosan egy idóben használt objektumok szétválogatására, az épülettípusok esetleges változásának megfigyelésére, jelentős településszerkezeti következtetések levonására nincsen lehetőség. Ugyanígy az egyes épületek funkciójával kapcsolatban sem állnak rendelkezésre egyértelmú adatok, meghatározó kisleletek vagy olyan természettudományos vizsgálatok, amelyek alapján az egykori munkafolyamatok helyszínét, tevékenységi körzeteket lehetne elkülöníteni a településeken belül. ${ }^{64}$ Ezek hiányában lehetséges, hogy a nagyméretú felszíni épületek kivétel nélkül kiegészítő gazdasági helyiségek, állattartással kapcsolatos építmények voltak. Ugyanakkor az sem cáfolható, hogy a kisebb alapterületú, földbe mélyített padlójú épületek mellett a felmenó fallal rendelkező, illetve a földfelszíni építmények is lakótérként szolgáltak, és a hagyományosan házként értelmezett kisebb épületek egy részét csupán másodlagos gazdasági egységekként, múhelyekként használták. ${ }^{65}$

Habár a rendeltetés kérdése egyelőre biztos válasz nélkül marad, a rákóczifalvi épületmaradványok és egyre nagyobb számban előforduló párhuzamaik egyértelmúen bizonyítják, hogy az avar kori telepeken sokkal változatosabb építészeti megoldásokkal számolhatunk, mint amit a kutatás sokáig bizonyítani tudott.

\section{IRODALOM}

BAJKAi ROZÁliA

2012a Egy késő avar kori település kutatási lehetőségei az Alföld északi peremén. Hajdúnánás-Mácsi-dúlő. In: Liska A.-Szatmári I. (szerk.): Sötét idők rejtélyei. 6-11. századi régészeti emlékek a Kárpát-medencében és környékén. A 2011-ben Békéscsabán megrendezett konferencián elhangzott előadások. Békéscsaba, 9-44.

2012b Avar kori településrészletek Kántorjánosi és Pócspetri határában. In: Szabó Á.-Masek Zs. (szerk.): Ante Viam Stratam. A Magyar Nemzeti Múzeum megelőző feltárásai Kántorjánosi és Pócspetri határában az M3 autópálya nyírségi nyomvonalában. Budapest, 407-480.

2014 Késő avar kori település Hajdúnánás határában. Debreceni Déri Múzeum Évkönyve 85, 29-60.

BÁLINT, CSANÁD

1991 Die spätawarenzeitliche Siedlung von Eperjes (Kom. Csongrád). Varia Archaeologica Hungarica 4. Budapest.

63 MadARAs 1989; MesterhÁZy 2002, 87; TAKÁCS 2002, 284-285.

64 A tevékenységi körzetek, ún. „aktivitási zónák” vizsgálati lehetőségeiről lásd: KALLA 2013, 11-14, 16-21 (részletes irodalmi gyújtéssel).

65 A Kölkeden feltárt 7. századi felszíni épületek jelenléte alapján Hajnal Zsuzsanna a kora avar kori, földbe mélyített épületek egy részét melléképületként értelmezte: HAJNAL 2009,105 . Zillingtal avar kori lelőhelyen az oszlopszerkezetes épület kapcsán a lakó- és karámfunkció egyaránt felmerült, mivel ezek alátámasztására vagy cáfolására sem álltak rendelkezésre adatok: Herold 2010, 110. Más korszakok telepeivel kapcsolatban szintén többször felvetődött a kérdés, hogy a dominánsnak túnő, földbe mélyített épületek mellett vajon milyen számban fordultak elő földfelszíni épületek, ezek milyen funkcióval bírtak, és használhatták-e óket lakóházként: TAKÁCS 2002, 274, 278; SKRIBA-SÓFALVI 2004. A gepida kutatásban felmerült, hogy a földbe mélyített épületeket kiegészítő, felmenő falú épületek hiánya, illetve kis száma a mélyszántás gyakorlatával és az ásatási módszerekkel magyarázható. Ezt támaszthatják alá azok a korabeli források, amelyekben a gödörházak gazdasági melléképületként, szerszámoskamraként és egyéb háztartási tevékenységek színhelyeiként szerepelnek: B. Tóтн 1991, 98-100. Mesterházy Károly felvázolta a 10-13. századi Európa három különböző építési gyakorlatot követő területét: e szerint Kelet-Európában a gödörházak többsége lakóházként volt használatban, míg nyugaton ezek csak melléképületként fordultak elő a nagyméretú földfelszíni épületek mellett. Véleménye szerint azonban amellett, hogy a gödörházak egy részét biztosan lakták, minden bizonnyal más épülettípusok jelenlétével is számolni lehet ezeken a telepeken: MESTERHÁzY 2002, 85-88. A „nyugati típusú” épületek elterjedésével és jellegével kapcsolatban ld. GUYAN 1952; DONAT 1980; ZIMMERMANN 1982; DONAT 1991; ZIMMERMANN 1998. 
BELÉNYesy KÁROLY-MERSDORF ZsuZSA

2004 Balatonőszöd, Temető-dúlő (M7/S10). Késő avar kori telepjelenségek. In: Kisfaludi J. (szerk.): Régészeti kutatások Magyarországon 2002 (Archaeological Investigations in Hungary, 2002). Budapest, 43-64.

BENEDEK ANDRÁs-PÓPITY DÁNIEL

2010 Késő avar kori településrészlet Szeged-Fertő, Jójárt-tanya területéről. In: Lőrinczy G. (szerk.): Pusztaszertől Algyőig. Móra Ferenc Múzeum Évkönyve - Monumenta Archeologica (Szeged) II, 193208.

BENKŐ ELEK

1984 Székelykeresztúri kályhacsempék. 15-17. század. Bukarest.

BÓNA ISTVÁN

1973 VII. századi avar települések és Árpád-kori magyar falu Dunaújvárosban (Awarische Siedlungen aus dem 7. Jahrhundert und ein ungarisches Dorf aus der Arpadenzeit [11-13. Jh.] in Dunaújváros). Fontes Archaeologici Hungariae. Budapest

1988 Vázlat a lakóházak történetéről a Kárpát-medencében. Bírálat Barabás Jenő: Fordulatok és korszakok a magyar népi építészetben címú doktori értekezésról. Ethnographia (Budapest) 99, 401-411.

BRATHER, SEBASTIAN

2001 Archäologie der westlichen Slawen. Siedlung, Wirtschaft und Gesellschaft im früh- und hochmittelalterlichen Ostmitteleuropa. Berlin-New York.

CZIFRA SZABOLCS

2006 Megjegyzések a szkíta kori Alföld-csoport veremházainak kérdéséhez (Bemerkungen zur Frage der Grubenhäuser der skythenzeitlichen Alföld-Gruppe). Archaeologiai Értesítő (Budapest) 131, 169-178.

CSEH JÁNOS

1989 Az avarok építkezése Szolnok-Zagyvaparton. In: Építészet az Alföldön I. Acta Musei de János Arany nominati - Nagykőrösi Arany János Múzeum Közleményei 6, 33-40.

K. CSILLÉRY KLÁRA

1982 A magyar népi lakáskultúra kialakulásának kezdetei. Budapest.

DÁM LÁSZLó

1993 Földbe mélyített lakóépítmények az Alföld népi építészetében. Jósa András Múzeum Évkönyve (Nyíregyháza) 33-35, 133-153.

DONAT, PETER

1980 Haus, Hof und Dorf in Mitteleuropa vom 7. bis 12. Jahrhundert. Archäologische Beiträge zur Entwicklung und Struktur der bäuerlichen Siedlung. Berlin.

1991 Zur Entwicklung germanischer Siedlungen östlich des Rheins bis zum Ausgang der Merowingerzeit.

FODOR ISTVÁN Zeitschrift für Archäologie (Berlin) 25, 149-176.

1989 Megjegyzések a középkori magyar lakóház fejlődéstörténetéhez. In: Cseri M.-Balassa M. I.-Viga Gy. (szerk.): Népi építészet a Kárpát-medence északkeleti térségében. Miskolc-Szentendre, 21-45.

1994 Árpád-kori boronaház nyomai Tiszaszigeten. In: Lőrinczy G. (szerk.): A kőkortól a középkorig. Szeged, 421-438.

2012 Avar kori lakóházak Hajdúnánáson (Awarenzeitliche Grubenhäuser in Hajdúnánás). In: Vida T. (szerk.): Thesaurus Avarorum. Régészeti tanulmányok Garam Éva tiszteletére. Archaeological Studies in Honour of Éva Garam. Budapest, 709-720.

GERGELY KATALIN

s. a. $\quad$ Avar kor végi boronaház Nagykálló-Harangod lelőhelyen. In: Merva Sz. (szerk.): Hadak Útján XXII. A Népvándorláskor Fiatal Kutatói XXII. Összejövetelének konferenciakötete. Visegrád, 2012. október 4-6. Budapest. Sajtó alatt.

GuYAN, WALTER UlRich

1952 Einige Karten zur Verbreitung des Grubenhauses in Mitteleuropa im ersten nachchristlichen Jahrtausend und einige Hinweise auf das archäologische Problem der völkerwanderungszeitlichen Hausformen der HABOVŠTIAK, ALOJZ Schweiz. Jahrbuch der Schweizerischen Gesellschaft für Urgeschichte (Basel) 42, 174-197.

1989 Régészeti adatok a középkori népi építészet tanulmányozásához Szlovákiából. In: Cseri M.-Balassa M. I.-Viga Gy. (szerk.): Népi építészet a Kárpát-medence északkeleti térségében. Miskolc-Szentendre, 7-20.

HAJNAL ZSUZSANNA

2009 Házak a Kölked-feketekapui avar kori telepen (Häuser in der awarenzeitlichen Siedlung KölkedFeketekapu). Archaeologiai Értesítő (Budapest) 134, 91-116.

Herold, HajNALKa

2004 Die frühmittelalterliche Siedlung von Örménykút 54. Teil I. Budapest.

2010 Zillingtal (Burgenland) - Die awarenzeitliche Siedlung und die Keramikfunde des Gräberfeldes. Monographien des Römisch-Germanischen Zentralmuseums Mainz 80. Mainz. 
HOFFMANN TAMÁS

1992 A faház (domus lignea) a középkori Európában. Ház és ember. A Szabadtéri Néprajzi Múzeum HOREDT, KURT Évkönyve (Szentendre) 8, 5-40.

1979 Morești. Grabungen in einer vor- und frühgeschichtlichen Siedlung in Siebenbürgen. Bukarest. HORVÁTH BÉLA

1968 Árpád-kori faépítkezés nyomai Fonyód-Bélatelepen (Les vestiges d'une construction en bois de l'époque Arpadienne á Fonyód). Folia Archaeologica (Budapest) 19, 113-144.

HORVÁTH ISTVÁN

1971 Esztergom-Kenderes-dúlő. Régészeti Füzetek (Budapest) Ser. I. No. 24, 65.

ILON GÁBOR

1996 Újabb régészeti adatok a középkori Pápa történetéhez. Pécs szabad királyi város Majorossy Imre

ISTVÁNFI GYULA Múzeumának Évkönyve 6, 297-317.

1997 Az építészet története. Őskor. Népi építészet. Budapest.

ISTVÁNOVITS ESZTER

2001 Korai szláv település maradványai Kisvárda határában (Reste einer frühslawischen Siedlung in der Gemarkung von Kisvárda). Jósa András Múzeum Évkönyve (Nyíregyháza) 43, 165-183.

KALLA GÁBOR

2013 A háztartások régészete mint kutatási probléma. Ősrégészeti Levelek/Prehistoric Newsletter (Budapest) 13, 9-36.

Kolozsi, BARBARA-SZABÓ, LÁsZLÓ

2005 An Avar Settlement on the Periphery of Hortobágy. In: Hum, L.-Gulyás, S.-Sümegi, P. (eds): Environmental Historical Studies from the Late Tertiary and Quaternary of Hungary. Szeged, 175-188.

KONDÉ ZsÓFIA

s. a. Tipológiai és időrendi megfigyelések Rákóczifalva-Bagi-földek lelőhely avar kori települési objektumain. In: Merva Sz. (szerk.): Hadak Útján XXII. A Népvándorláskor Fiatal Kutatói XXII. Összejövetelének konferenciakötete. Visegrád, 2012. október 4-6. Budapest. Sajtó alatt.

KovALOVSZKI JÚLIA

1975 Előzetes jelentés a dobozi Árpád-kori faluásatásról, 1962-1974 (Vorbericht über die Ausgrabung des arpadenzeitlichen Dorfes Doboz, 1962-1974). Archaeologiai Értesító (Budapest) 102, 204-223.

2001 Árpád-kori házak Visegrád-Várkertben. In: Cseri M.-Tárnoki J. (szerk.): Népi építészet a Kárpátmedencében a honfoglalástól a 18. századig. Szentendre-Szolnok, 81-98.

KovÁcs Katalin-SebőK Katalin-Szabó GÁbOr-VÁcZi GÁbOr

2007 Rákóczifalva, Bagi-föld (8/a sz. lh.). In: Kisfaludi J. (szerk.): Régészeti Kutatások Magyarországon 2006. (Archaeological Investigations in Hungary 2006). Budapest, 261-262.

2008 Rákóczifalva, Bagi-föld, 8/a sz. lelőhely. In: Kisfaludi J. (szerk.): Régészeti Kutatások Magyarországon 2007. (Archaeological Investigations in Hungary 2007). Budapest, 266-267.

KRASKOVSKÁ, LUDMILA

1961 Slovenské Sídlisko pri Devínskom Jazere. Slovenská Archeológia (Nitra) 9/1-2, 391-404.

KRÜGER, BRUNO

1964 Eine altslawische Siedlung in Dessau-Mosigkau. Ausgrabungen und Funde. Nachrichtenblatt für Vorund Frühgeschichte (Berlin) 9/1, 42-50.

LASZLOVSZKY JÓZSEF

1982 Karámok Árpád-kori falvainkban. Talajfoszfát-analízis alkalmazása az árkok szerepének meghatározásánál (Pferche in unseren arpadenzeitlichen Dörfern). Archaeologiai Értesítő (Budapest) 109, 281-285.

LÁSZLó GYULA

1978 Felgyő-Ürmös tanya (Csongrád megye). Régészeti Füzetek (Budapest) I. Ser. 1. No. 31, 74-75.

LÁZÁr SAROLTA

1998 Árpád-kori település Esztergom-Szentgyörgymezőn. Opuscula Hungarica I. Budapest.

LISKA ANDRÁS

2004 Késő avar kori településmaradványok Gyula határában (Gyula 425. sz. lelőhely). In: Kisfaludi J. (szerk.): Régészeti Kutatások Magyarországon 2002. (Archaeological Investigations in Hungary 2002). Budapest, 65-80.

MÁCSAI VIKTOR

2011 A Rákóczifalva-Bagi-földek 8.A avar temetőjének feldolgozása. Szakdolgozat ELTE BTK. Budapest.

MADARAS LÁSZLÓ

1986 Az avar kori telepkutatás újabb eredményei az Alföld központi területén. In: Novák L.-Selmeczi L. (szerk.): Falvak, mezóvárosok az Alföldön. Acta Musei de János Arany nominati IV. Nagykőrös, 33-65.

1991 Az avar falu. Régészeti ásatások Tiszafüred-Morotvaparton. Szolnok megyei adattár 32. Szolnok. 
MASEK ZSÓFIA

2009 Egy kora népvándorlás kori településrészlet leletanyagának értelmezése (Rákóczifalva-Bagi-földek 5. lelőhely). Szakdolgozat ELTE BTK. Budapest.

2012 Kora népvándorlás kori települések kutatása Rákóczifalva-Bagi-földek 5. - 8. - 8.A lelőhelyek területén. In: Petkes Zs. (szerk.): Hadak Útján XX. Népvándorláskor Fiatal Kutatói XX. Összejövetelének konferenciakötete. Budapest-Szigethalom, 2010. október 28-30. Budapest, 43-59.

MÉRI ISTVÁN

1952 Beszámoló a tiszlök-rázompusztai és túrkeve-mórici ásatások eredményeiről I. (Bericht über die Resultate der Ausgrabungen von Tiszalök-Rázompuszta und Túrkeve-Móric I). Archaeologiai Értesítő (Budapest) 79, 49-67.

1962 Az árkok szerepe Árpád-kori falvainkban (Angaben zur Siedlungsform der arpadenzeitlichen ungarischen Dörfer). Archaeologiai Értesítő (Budapest) 89, 211-219.

MESTERHÁZY KÁROLY

2002 Gödörház-változatok Magyarországon térben és időben. In: Kissné Cseh J. (szerk.): Központok és falvak a honfoglalás és kora Árpád-kori Magyarországon. Tatabánya, 85-93.

Pleinerová, IVANA

1979 Zu den frühslawischen Grubenhäusern. In: Chropovský, B. (éd.): Rappaports du III Congrès International d'Archéologie Slave. Bratislava, 7-14 septembre 1975. Bratislava, 629-637.

1986 Březno: Experiments with building old Slavic houses and living in them. Památky Archaeologické (Praha) 77, 104-176.

RENFrew, COLIN-BAHN, PAUL

1999 Régészet. Elmélet, módszer, gyakorlat. Budapest.

RÓZSA ZOLTÁN

2002 Avar kori teleprészlet Kardoskúton (Avar settlement in Kardoskút). Békés Megyei Múzeumok

RutTKAY, MATEJ Közleményei (Békéscsaba) 23, 115-143.

2002 Der ländliche Hausbau des 5. bis 15. Jh. im nördlichen Karpatenbecken (Slowakei). In: Klápšte, J. (ed.): Ruralia 4: The rural house from the Migration Period to the oldest still standing buildings. Kongress vom 08.-13. September 2001 at Bederkesa, Lower Saxony. Prague, 264-271.

SABJÁN TiBOR

1999 A lakóház rekonstrukciója. In: Bencze Z.-Gyulai F.-Sabján T.-Takács M. (szerk.): Egy Árpád-kori veremház feltárása és rekonstrukciója. Monumenta Historica Budapestinensia X. Budapest, 131-176.

SABJÁN TiBOR-BuZÁs GERGELY

2003 Hagyományos falak. Népi kultúra. Budapest.

ŠALKOVSKÝ, PETER

2001 Häuser in der frühmittelalterlichen slawischen Welt. Nitra.

2009 Frühmittelalterliche Grubenhäuser. Probleme der Terminologie, Typologie und Rekonstruktion. Archaeologia Adriatica (Zadar) III, 273-292.

2011 Das frühmittelalterliche Dorf im Karpatenbecken. In: Kolozsi B.-Szilágyi K. A. (szerk.): Sötét idők falvai. 2006-ban Debrecenben megrendezett konferencia 2. kötete. Debrecen, 419-450.

SCHMid, Magdalena M. E.

2009 Das spätawarenzeitliche Gräberfeld von Rákóczifalva, Kom. Jász-Nagykun-Szolnok. Magisterarbeit der Rheinischen Friedrich-Wilhelms-Universität zu Bonn. Bonn.

SKriba PÉTER-SÓfalvi ANDrÁs

2004 Langobárd település Balatonlelle határában (Eine Langobardensiedlung in der Gemarkung von

Cs. Sós ÁGNES Balatonlelle). Archaeologiai Értesító (Budapest) 129, 121-163.

1984 Zalavár-Kövecses. Ausgrabungen 1976-78. Anhang: István Vörös: Knochenfunde. Régészeti Füzetek (Budapest) Ser. II. No. 24.

Stadler, Peter-Herold, HajnalKa

2003 Drei awarenzeitliche Brunnen und sonstige Siedlungsgruben von Brunn am Gebirge (Flur Wolfholz, Bezirk Mödling, NÖ) und die Fundkeramik. Antaeus. Communicationes ex Instituto Archaeologico Scientiarum Hungaricae (Budapest) 26, 179-186.

SZABÓ GÁBOR-SEBÖK KATALIN

2007a Rákóczifalva, Bagi-föld (2. sz. lh.). In: Kisfaludi J. (szerk.): Régészeti Kutatások Magyarországon 2006. (Archaeological Investigations in Hungary 2006). Budapest, 260.

2007b Rákóczifalva, Bagi-föld (5. sz. lh.). In: Kisfaludi J. (szerk.): Régészeti Kutatások Magyarországon 2006. (Archaeological Investigations in Hungary 2006). Budapest, 260-261.

SZABÓ J. JÓZSEF

1978 Népvándorláskori teleprészlet és Árpád-kori településnyomok Battonya határában. Békés Megyei Múzeumok Közleményei (Békéscsaba) 5, 61-86. 
SZABÓ LÁSZLÓ

1975 Néprajzi párhuzam Árpád-kori falvaink árkainak rendeltetéséhez (Paralléle ethnographique cocernant la destination des fossés des villages de l'époque Arpadienne). Archaeologiai Értesítő (Budapest) 102, $84-87$.

B. SZATMÁRI SAROLTA

1983 Avar temető- és telepásatás Tatabánya-Alsógalla mellett. Szolnok Megyei Múzeumok Évkönyve (Szolnok) 67-79.

SZŐKE BÉLA MiKLÓS

1992 7. és 9. századi településmaradványok Nagykanizsán (Siedlungsreste aus dem 7. und 9. Jh. in Nagykanizsa, SW-Ungarn). Zalai Múzeum (Zalaegerszeg) 4, 129-167.

2008 Kora avar kori veremház Balatonmagyaród-Hídvégpusztán (Ein frühawarenzeitliches Halbgrubenhaus in Balatonmagyaród-Hídvégpuszta). Zalai Múzeum (Zalaegerszeg) 17, 209-220.

TAKÁCS MiKLÓS

1993 Falusi lakóházak és egyéb építmények a Kisalföldön a 10-16. században (Kutatási eredmények és további feladatok). In: Perger Gy.-Cseri M. (szerk.): A Kisalföld népi építészete. Szentendre-Győr, 33-34.

1996 Die awarenzeitlichen Siedlungen von Lébény. In: Daim, F. (Hrsg.): Hunnen und Awaren. Reitervölker aus dem Osten. Burgenländische Landesausstellung 1996, Schloß Halbturn, vom 26. April bis 31. Oktober 1996. Begleitbuch und Katalog. Eisenstadt, 379-382.

1999 Lakóház-rekonstrukciók az Árpád-kori telepkutatásban (Tudománytörténeti áttekintés). In: Bencze Z.Gyulai F.-Sabján T.-Takács M. (szerk.): Egy Árpád-kori veremház feltárása és rekonstrukciója. Monumenta Historica Budapestinensia X. Budapest, 93-108.

2001 Az Árpád-kori köznépi lakóház kutatása, különös tekintettel az 1990-es évekre. In: Cseri M.-Tárnoki J. (szerk.): Népi építészet a Kárpát-medencében a honfoglalástól a 18. századig. Szentendre-Szolnok, 7-54.

2002 Der Hausbau in Ungarn vom 2. bis zum 13. Jahrhundert n. Chr. - Ein Zeitalter einheitlicher Grubenhäuser? In: Klápšte, J. (ed.): Ruralia 4: The rural house from the Migration Period to the oldest still standing buildings. Kongress vom 08.-13. September 2001 at Bederkesa, Lower Saxony. Prague, 272-290.

TARI EDIT

2001 Faépületek az Árpád-kori népi építészetben. In: Cseri M.-Tárnoki J. (szerk.): Népi építészet a Kárpátmedencében a honfoglalástól a 18. századig. Szentendre-Szolnok, 157-186.

TÍMÁR, LŐRINC

2008 A Computer Aided Study of Late Iron Age Buildings. In: E. Jerem-F. Redő-V. Szeverényi (eds): On the Road to Reconstructing the Past. Computer Applications and Quantitative Methods in Archaeology. Proceedings of the $36^{\text {th }}$ International Conference, Budapest, 2-6 April 2008. Budapest, 399-405.

TOMKA PÉTER

1988 Avar kori település Győr, Bokányi Dezső utcában (Siedlung aus der Awarenzeit in der Bokányi-Straße von Győr). Arrabona. A Győri Xantus János Múzeum Évkönyve 24-25 (1982-1983), 35-61.

1998 A sopronkőhidai 9. századi település (Siedlung aus dem 9. Jahrhundert bei Sopronkőhida). Arrabona. A Győri Xantus János Múzeum Évkönyve 36/1-2, 45-84.

2003 Die awarischen Brunnen in der Kleinen Tiefebene. Antaeus. Communicationes ex Instituto Archaeologico Scientiarum Hungaricae (Budapest) 26, 159-177.

2004 Kleine Öfen - Große Wannen. Die Besonderheiten einer spätawarenzeitlichen Siedlung. In: G. Fusek (ed.): Zborník na počest' Dariny Bialekovej. Nitra, 419-426.

B. Tóth ÁGNES

1991 Gepida településnyomok a Körös-Tisza-Maros közén. In: Lőrinczy G. (szerk.): A népvándorlás fiatal kutatóinak szentesi találkozóján elhangzott előadások. Móra Ferenc Múzeum Évkönyve (Szeged) 1984-1985/2, 97-104.

2006 Gepidische Siedlungen im Theißgebiet. Monumenta Germanorum Archaeologica Hungariae Vol. 4. Monumenta Gepidica. Budapest.

TROGMAYER OTTÓ

1962 Népvándorláskori telepnyomok Bokros határában (Siedlungsspuren aus der Völkerwanderungszeit im TRUGLY SÁNDOR Gebiet von Bokros). Móra Ferenc Múzeum Évkönyve (Szeged) 1960-1962, 3-8.

1996 A komáromi avar telep. Communicationes Archaeologicae Hungariae (Budapest), 125-150.

VÁCZI GÁBOR-KOVÁcs KATALIN

2007a Rákóczifalva, Bagi-föld (8. sz. lh.). In: Kisfaludi J. (szerk.): Régészeti Kutatások Magyarországon 2006. (Archaeological Investigations in Hungary 2006). Budapest, 261.

2007b Rákóczifalva, Bagi-föld (12. sz. lh.). In: Kisfaludi J. (szerk.): Régészeti Kutatások Magyarországon 2006. (Archaeological Investigations in Hungary 2006). Budapest, 262-263. 
VADAY ANDREA

1999 Az avar kori telep. In: Petercsák T.-Szabó J. J. (szerk.): Kompolt-Kistér. Újkőkori, bronzkori, szarmata és avar lelőhely. Leletmentő ásatás az M3-as autópálya nyomvonalában. Eger, 233-253.

VÁRADI ADÉL

2000 Előzetes jelentés a Nagyút határában feltárt római és késő népvándorlás kori teleprészletekről. In: Bende VIDA, TIVADAR L.-Lőrinczy G.-Szalontai Cs. (szerk.): Hadak útján. Szeged, 125-153.

1996 Avar Period Settlement Remains and Graves at the site of Gyoma 133. In: Vaday A. (szerk.): Cultural and Landscape Changes in South-East Hungary II. Perhistoric, Roman Barbarian and Late Avar Settlement at Gyoma 133 (Békés County Microregion). Budapest, 323-364.

2011 Sütőharangok és sütőfedők - Régészeti adatok Dél- és Közép-Európa étkezési kultúrájához. In: Kolozsi B.-Szilágyi K. A. (szerk.): Sötét idők falvai. 2006-ban Debrecenben megrendezett konferencia 2. kötete. Debrecen, 701-817.

ZÁBOJNIK, JOZEF

1988 On the Problems of Settlements of the Avar Khaganate Period in Slovakia. Archeologické Rozhledy (Nitra) 40/4, 401-437.

ZAY ORSOLYA

2013 Egy Árpád-kori veremház rekonstrukciója. In: Varga M. (szerk.): Fiatal Középkoros Régészek IV. Konferenciájának Tanulmánykötete. A Kaposváron 2012. november 22-24. között megrendezett Fiatal Középkoros Régészek IV. Konferenciájának tanulmányai. Rippl-Rónai Múzeum Közleményei (Kaposvár), 33-40.

ZIMMERMANN, WOLFRAM-HAIO

1982 Archäologische Befunde frühmittelalterlicher Webhäuser. Ein Beitrag zum Gewichtswebstuhl. Jahrbuch der Männer vom Morgenstern (Bremerhaven) 61, 111-144.

1998 Pfosten, Ständer und Schwelle und der Übergang vom Pfosten- zum Ständerbau. Eine Studie zu Innovation und Beharrung im Hausbau. $\mathrm{Zu}$ Konstruktion und Haltbarkeit prähistorischer bis neuzeitlicher Holzbauten von den Nord- und Ostseeländern bis zu den Alpen. Probleme der Küstenforschung im südlichen Nordseegebiet (Oldenburg) 25, 9-241.

\section{SUNKEN AND ABOVE-GROUND BUILDINGS OF THE AVAR PERIOD AT THE RÁKÓCZIFALVA-BAGI-FÖLDEK SITE}

\section{ZSÓFIA KONDÉ}

Five sites with a larger spatial extent marked with different numerals were uncovered during the salvage excavation conducted in 2006-2007 near Rákóczifalva in County Jász-Nagykun-Szolnok (Fig. 1). The RákóczifalvaBagi-földek site was occupied from the Neolithic through the Sarmatian and Gepidic period to the late Avar period. The settlement features of the 8th-9th-century Avar period settlement covered a roughly 1.5 hectares large area.

The settlement features uncovered on the site included the remains of 45 sunken buildings, which could be assigned to ten different types based on the post-holes inside them and the remnants of the wall and roof structure (Fig. 2). The reconstructed buildings represented four structural types (Fig. 8). The reconstruction of buildings without any post-holes or with merely a single post-hole (Types 1 and 3.a-d) proved to be the most difficult; it seems likely that some of these had a roof structure of purlins supported by forked ridge poles resembling those of most other buildings, even though traces of the post-holes were not preserved (Fig. 3.03, 20, 22, 23; Fig. $4.34,37,55$; Fig. 5.1, 4). Other buildings in this group were probably log cabin-like buildings with upright walls, which, however, leave no traces in the archaeological record (Fig. 3.12, 13, 15, 27, 32; Fig. 4.36, 40, 41, 47, 49-51, 59,
61). The second structural group is made up of the sunken buildings which, similarly to most Avar period houses, have two or three forked ridge poles and a pitched roof (Fig. 3.02, 05, 06, 17, 19, 29; Fig. 4.38, 39, 42$46,48,52-54,56,58,60)$. The post-holes in some of the buildings in this group have an irregular arrangement: in addition to the two forked ridge poles with a static role, the other posts were auxiliary with a bracing function (Fig. 3.02, 05, 17). The two buildings assigned to the third group can be reconstructed as structures with vertical walls of daubed wattling (Fig. 3.04, 21; Fig. 5.3), which have few known parallels from the currently known Avar period settlements. One building represents a fourth structural type characterised by a sunken floor with mortised ground sills set into foundation ditches (Fig. 3.33; Fig. 6.1-3). In the case of this building, the walls most likely resembled the upright walls of a log cabin set into the ground sills (Fig. 6.4-5): reckoning with $1 \mathrm{~m}$ high walls and a roof pitched at $45^{\circ}$, the building had a comfortable interior height of over $2 \mathrm{~m}$ (Fig. 6.6-9). Although many specialists of the Avar period had suggested the possible existence of above-ground houses with upright walls, little survived of these in the archaeological record and buildings of this type were exclusively known from later settlements. Very few building remains that unmis- 
takably represented structures with upright walls have been published from the Avar period to date.

In addition to the sunken buildings, several other structures outlined by post-holes were identified at the Rákóczifalva site, which can be reconstructed as structures with walls built around upright posts that had various functions. Their orientation and location was aligned to the other Avar period settlement features, implying that they had existed at the same time. One of the difficulties in their reconstruction is that some of the shallower post-holes associated with these structures were destroyed during the humus removal and that very few comparable structures are known from other Avar period settlements.

The smaller settlement features outlined by post-holes with a regular arrangement may have been residential structures with upright wattle-and-daub walls resembling the sunken, post-framed buildings (Types 9 and 10; Fig. 3.01, 14, 28; Fig. 4.35). It is possible that similarly to the Northern European longhouses and house-barns, the elongated rectangular buildings measuring $5 \mathrm{~m}$ by $20 \mathrm{~m}$ also functioned as residential buildings, even if possible floor and hearth remains had perished owing to their shallow depth from the modern surface (Fig. 3.26, 30; Fig. 7.2). The largest area with a coherent post-framed structure (Fig. 3.24; Fig. 7.1) can presumably be interpreted as a livestock enclosure system. The other, larger and more irregular structures can be reconstructed as various economic outbuildings such as stalls, windbreaks or deflector walls. Other features include shallower L-shaped or semicircular ditches that may once have been part of above-ground structures such as reed or wattle walls, ramparts and lean-to shelters, although they can equally well be regarded as marking the one-time location of buildings that have perished without a trace (Fig. 3.16, 18, 31).

The low number of finds recovered from the shallow post-holes and the relatively homogenous nature of the site's ceramic assemblage does not enable the secure identification of the contemporaneous buildings, the possible changes in various building types or far-reaching conclusions regarding settlement layout. Similarly, there is no conclusive evidence regarding the function of individual buildings in the lack of diagnostic small finds and archaeometric analyses that would allow the identification of activity areas or the location of craft activities within the settlement. It is possible that the large aboveground buildings were all economic structures associated with stockbreeding, but neither can we reject the possibility that in addition to the smaller sunken houses, some of the buildings with upright walls also had a residential function and that some of the smaller buildings usually interpreted as houses were used as secondary economic structures or workshops.

Although their function remains open to interpretation, the building remains uncovered at Rákóczifalva and the growing number of similar structures uncovered on other sites provide incontestable evidence that the architecture of Avar period settlements was much more varied and diverse than earlier believed. 